\title{
The Ronda Peridotite: Garnet-, Spinel-, and Plagioclase-Lherzolite Facies and the P-T Trajectories of a High-Temprature Mantle Intrusion
}

\author{
Journal Article \\ Author(s): \\ Masaaki, Obata \\ Publication date: \\ 1980 \\ Permanent link: \\ https://doi.org/10.3929/ethz-b-000422842 \\ Rights / license: \\ In Copyright - Non-Commercial Use Permitted \\ Originally published in: \\ Journal of Petrology 21(3), https://doi.org/10.1093/petrology/21.3.533
}




\title{
The Ronda Peridotite: Garnet-, Spinel-, and Plagioclase-Lherzolite Facies and the $P-T$ Trajectories of a High-Temperature Mantle Intrusion
}

\author{
by MASAAKI OBATA* \\ Institut für Kristallographie und Petrographie, Eidgenössische Technische Hochschule, Zürich, \\ CH-8092, Zürich, Switzerland
}

(Received 18 October 1978; in revised form 28 June 1979)

\begin{abstract}
The Ronda peridotite is a high-temperature, alpine-type peridotite emplaced in the internal Zone of the Betic Cordilleras, southern Spain. Using the mineral assemblages of the peridotite and mafic layers, the peridotite mass has been subdivided into 4 zones of mineral facies: (1) garnet-lherzolite facies, (2) ariégite subfacies of spinel-lherzolite facies, (3) seiland subfacies of spinel-lherzolite facies, and (4) plagioclase-lherzolite facies. It is proposed that this mineralogical zonation developed through a syntectic recrystallization of a hot $\left(1100\right.$ to $\left.1200^{\circ} \mathrm{C}\right)$, solid mantle peridotite during its ascent into the Earth's crust.

Coexisting minerals from 12 peridotites covering all the mineral facies above were analysed with an electron microprobe. Core compositions of pyroxene porphyroclasts are constant in all mineral facies and indicate that the peridotite was initially equilibrated at temperatures of 1100 to $1200^{\circ} \mathrm{C}$ and pressures of 20 to $25 \mathrm{~kb}$. In contrast, the compositions of pyroxene neoblasts and spinel grains (which appear to have grown during later recrystallization) are well correlated with mineral facies. They indicate that the recrystallization temperature throughout the mass is more or less constant, 800 to $900^{\circ} \mathrm{C}$, but that the pressure ranges from $5-7 \mathrm{~kb}$ in the plagioclase-lherzolite facies to $12-15 \mathrm{~kb}$ in the garnet-lherzolite facies. Therefore, variation in pressure appears to be primarily responsible for the four mineral facies types.

A pressure range of at least $5 \mathrm{~kb}$ appears to be too large to have been maintained (at the same time) in a mass as small as the Ronda peridotite. Dynamic cooling may explain the observed variation in the recrystallization pressure; i.e. during the intrusion of the peridotite body, different parts of the body have followed different $P-T$ paths in response to different local cooling rates. Comparing the inferred $P-T$ paths for the peridotite with published melting temperature of peridotite and mafic rocks, it is concluded that the peridotite did not go through partial fusion during the ascent. A hypothetical, diapiric uprise that caused partial fusion and igneous differentiation of the mantle peridotite is considered to be a separate event prior to the ascent that started from about 70 $\mathrm{km}$ depth in the upper mantle. Estimates of cooling rates and of Al diffusion rates in pyroxenes suggest that the ascent rate of the peridotite body was greater than 1 meter/year.
\end{abstract}

\section{INTRODUCTION}

T HE Ronda peridotite mass, a mountainous terrane of ultramafic and mafic rocks, is known as the world's largest $\left(300 \mathrm{~km}^{2}\right)$ and best exposed high-temperature peridotite intrusion (Dickey, 1970). It is distinguished by a contact metamorphic aureole, high-pressure mineralogies, and chemistry relatively undepleted in basaltic components (Green, 1967). In addition, the Ronda peridotite is unique in that within a single peridotite mass all three important peridotite mineral facies, garnet-,

* Present address: Department of Earth Sciences, Toyama University, Gofuku, Toyama 930, Japan.

|Journal of Petrology, Vol. 21, Part 3, pp. 533-572, 1980] 
spinel-, and plagioclase-lherzolite (O'Hara, 1967), occur in geographic succession. Therefore, it offers an excellent opportunity to study, in a geologic framework, the systematics of the mineral parageneses and mineral chemistry of peridotite and associated rocks.

Geological and petrological work on the Ronda peridotite was first published by Orueta (1917). Dickey (1970) restudied the peridotite and, in particular, the mafic layers and proposed that these layers are partial fusion products of the peridotite in an ascending mantle.diapir. The origin of the mafic layers has been further investigated with more geochemical and experimental data (Obata \& Dickey, 1976; Dickey et al., 1978; Suen, 1978). Although Dickey (1970) noted substantial subsolidus changes in mineralogy of the mafic layers, he believed that some layers still partially retain their magmatic mineralogies. Recent structural (Darot, 1973; Lundeen, 1976) and petrological work (Obata, 1977; Schubert, 1977), however, suggest that the extent of deformation and subsolidus recrystallization is greater than previously thought. As with many other alpine-type peridotites, deformation and metamorphism have more or less obscured primary textures and mineralogies; therefore, evaluation of the metamorphic effects is a prerequisite for discussions of igneous differentiation processes such as partial fusion or fractional crystallization.

This paper deals with the petrology and mineral chemistry of the peridotite and the mafic layers from the Ronda peridotite mass. Mineral chemistry is discussed in detail because many minerals reveal chemical inhomogeneities. The equilibrium conditions are inferred from the petrological and mineral-chemical data, thus providing important petrologic constraints on the nature and the history of the peridotite intrusion. Geologic details are published elsewhere with a 1:50,000 scale geologic map (Lundeen et al., 1977).

\section{GEOLOGIC BACKGROUND}

The peridotite mass is located in the west end of the Internal Zone of the Betic Cordilleras near the Mediterranean coast, southern Spain (fig. 2 in Dickey, 1970). Structurally, the peridotite is a slab, approximately $1.5 \mathrm{~km}$ thick, sandwiched between the Casares Unit above and the Blanca Unit below (Lundeen, 1978). The Casares Unit-peridotite complex has been interpreted as a western continuation of the Alpujarride nappe complex identified farther to the east in the Internal Zone (Dürr, 1967). The Blanca Unit has been correlated with the deepest member of the Internal Zone, the Nevado-Filabride complex (Egeler \& Simon, 1969). Covering them all is the Malaguide nappe, structurally the highest unit of the Internal Zone.

The peridotite has a distinct metamorphic aureole in the Casares Unit. Paleozoic pelitic sediments range from chlorite-sericite phyllite $6 \mathrm{~km}$ away from the peridotite contact, through mica-andalusite schist up to garnet-cordieritesillimanite gneiss at the contact (Loomis, 1972a). A contact aureole is also present in the Blanca Unit beneath the peridotite, but there it is much thinner and is characterized by a lower-pressure sequence than the Casares contact (hornfels series of Loomis, 1972a; see Lundeen, 1978 for more detail). 


\section{PERIDOTITE}

The peridotite consists of olivine, orthopyroxene (enstatite), clinopyroxene (diopside) and various aluminous phases (see below). A small amount of secondary hornblende $(0.1$ to $0.2 \mathrm{~mm}$ size) occurs in some samples. Different kinds of aluminous phases are encountered depending upon the position in the mass: $\mathrm{Cr}-\mathrm{Al}$ spinel throughout the mass, calcic plagioclase (An60-80) in the eastern and the southeastern parts of the mass, and pyropic garnet in the northwest (Fig. $3 a$, see later discussion). Garnet and plagioclase never coexist in the peridotite. According to the dominating aluminous phases and depending on its pyroxene contents, peridotite is called garnet, spinel and plagioclase lherzolite or harzburgite, following the classification system adopted by the International Union of Geological Sciences Subcommission on the Systematics of Igneous Rocks (Streckeisen, 1976). Some peridotite samples have transitional features between spinel and plagioclase peridotites, characterized by having spinel grains surrounded by plagioclase (see below). They are called spinel-plagioclase transitional peridotite or, in short, transitional peridotite.

Much of the Ronda peridotite is porphyroclastic in the sense of Mercier \& Nicolas (1975). It is characterized by two habits of olivine and enstatite grains: large, elongated, strained grains (porphyrociasts) and small, polygonal, strain-free grains (neoblasts). Peridotite from the middle portion of the mass is very coarse-grained $(2 \mathrm{~mm}$ to $1 \mathrm{~cm}$ ), is little deformed, and has many features in common with the protogranular textures defined by Mercier \& Nicolas (1975). The degree of deformation, expressed by (a) reduced grain sizes, (b) enstatite porphyroclasts stretched by translation gliding, and (c) the development of strong foliation and preferred orientation, increases toward the northwestern contact (Darot, 1973; Lundeen, 1976). Plagioclase peridotites in the southeast have partially annealed textures but still retain their former record of deformation. The texture is characterized by straight grain boundaries, $120^{\circ}$-triple junctions of neoblasts, and diminished undulose extinction and sharp kink boundaries in the porphyroclasts. Mylonitic textures have locally developed, particularly at the boundaries between the mafic layer and the peridotite.

\section{Orthopyroxenes}

Orthopyroxene porphyroclasts have abundant exsolution lamellae of clinopyroxene and, in some cases, blebs of clinopyroxene. The clinopyroxene lamellae are partly replaced by amphibole lamellae in some specimens. Less commonly, thin lamellae of plagioclase occur parallel to (100) of the host, but it may be difficult to recognize them because most are altered to saussurite. Plagioclase relicts, often with albite twinning, however, may be found in blebs at the termination of the plagioclase lamellae (Fig. 1). Some orthopyroxene grains are partly replaced by talc, particularly along rock fractures. Olivine inclusions and embayments are conspicuous in orthopyroxene porphyroclasts and sometimes spinel is associated with the olivine inclusions (Fig. 6).

Orthopyroxene neoblasts are optically clear and rarely contain clinopyroxene exsolution lamellae. Both neoblasts and porphyroclasts contain a few small (20 to 


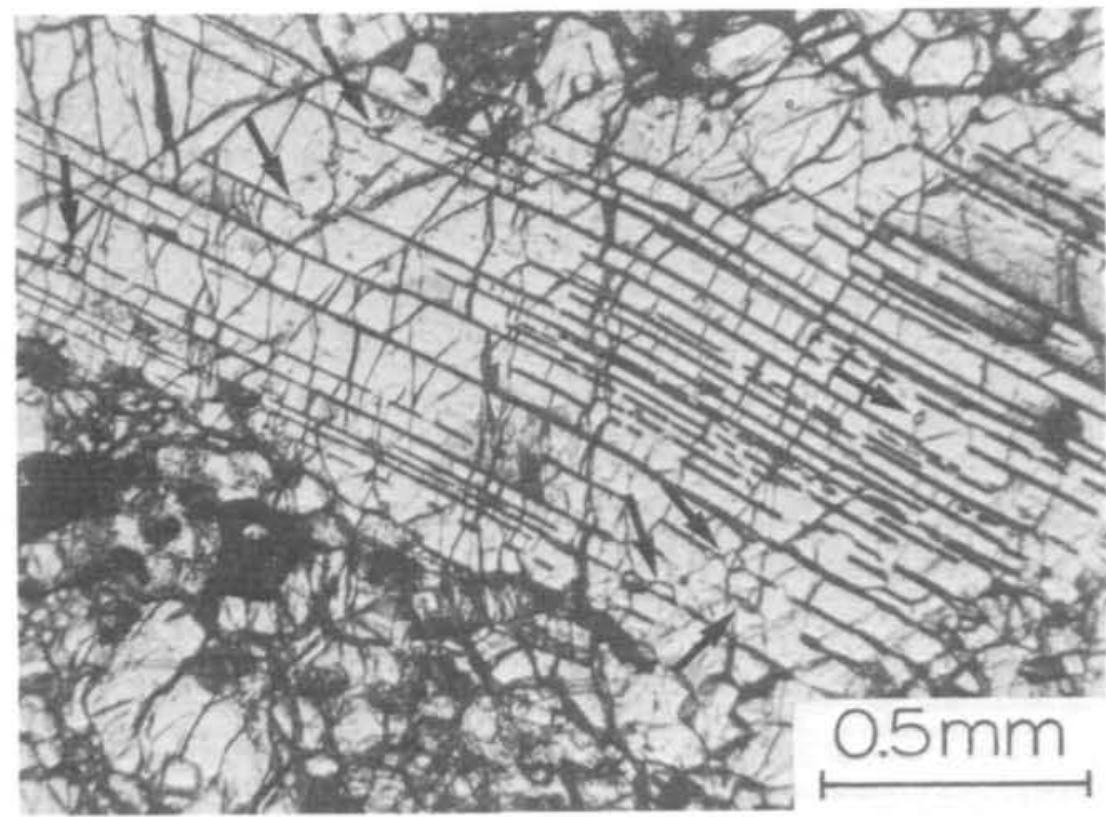

FIG. 1. Plagioclase lamellae (black sharp lines like cleavages) and blebs (indicated by arrows) in an orthopyroxene porphyroclast, transitional peridotite R37.

$30 \mu$ ), round inclusions with lower refractive indices than the pyroxene hosts. Similar inclusions are also observed in olivine grains.

\section{Clinopyroxenes}

Clinopyroxene grain size is more or less continuous from 0.2 to $3 \mathrm{~mm}$, and the distinction between porphyroclast and neoblast is not always clear. In general, small $(\sim 0.2 \mathrm{~mm})$, polygonal clinopyroxene grains occur around orthopyroxene porphyroclasts or in clinopyroxene-rich aggregates, 2 to $3 \mathrm{~mm}$ in diameter, in an olivine matrix. Such pyroxene aggregates may have been formerly single, large clinopyroxene grains which were later polygonized by deformation. Most clinopyroxene grains have one set of orthopyroxene exsolution lamellae parallel to (100), but some grains have two sets of lamellae (of pyroxene?) with different orientations. Plagioclase lamellae occur in some coarse, clinopyroxene grains and are often, like those in the orthopyroxene grains, saussuritized. Small $(\sim 10 \mu)$ brown spinel grains also occur in the saussurites. Some clinopyroxene grains in spinel lherzolite are turbid due to numerous tiny, subrectangular inclusions $(<4 \mu$ in length) with lower refractive index than the host pyroxenes, parallel to the crystallographic $c$-axis of the pyroxene.

\section{Spinels}

The size, shape and color of spinel vary depending upon rock type. In spinel lherzolite, spinel is pale greenish brown and occurs as irregular grains of 0.2 to 1 $\mathrm{mm}$ size. Coarse, vermicular intergrowths $(0.07$ to $0.2 \mathrm{~mm}$ thick) of spinel and clinopyroxene in orthopyroxene porphyroclasts occur in some coarse spinel 
lherzolite. From textural relations, much of the spinel appears to have formed by exsolution from aluminous pyroxenes. In spinel-plagioclase transitional peridotite, larger spinel grains ( 1 to $1.5 \mathrm{~mm}$ ) are distinctly zoned from pale brown or pale greenish-brown cores to reddish-brown rims. Outlines of the grains are irregular, and they are always surrounded by plagioclase. Small spinel grains $(0.1$ to 0.2 $\mathrm{mm}$ ), also surrounded by plagioclase, are reddish-brown to nearly opaque. Aluminous spinels are apparently reacting with pyroxenes to form plagioclase and olivine, leaving the chromium behind in the residual spinel (as described in the Lizard peridotite by Green, 1964, p. 169; see Mineral Chemistry). In plagioclase peridotite, spinel is sparse, typically less than one volume per cent, and occurs as dark brown to opaque amoeboid-shaped grains surrounded by plagioclase, like the small grains in the spinel-plagioclase transitional peridotite.

In garnet peridotite, spinel occurs as either brown, irregular-shaped, large grains $(0.3$ to $0.7 \mathrm{~mm})$ or tiny $(\sim 20 \mu)$, pale brown grains. Typically, only a few large grains occur in a thin section; some have slightly lighter-colored rims than cores. Tiny spinels are numerous and dispersed in serpentinized, olivine matrices. Many of them contain thin $(\sim 1 \mu)$ sulfide veins (pyrrhotite?). In pyroxene-poor harzburgites and dunites, spinel is darker reddish brown and is typically coarse (up to $1 \mathrm{~mm}$ ) and euhedral.

\section{Garnets}

Garnet peridotite has not been previously reported as a rock type from the Ronda peridotite, so it is described in some detail here. Pink to red, pyropic garnet occurs sporadically in the peridotite in the northwest part of the mass (Fig. 3a). Garnet grains are generally aligned parallel to the foliation, and they are partially to completely kelyphitized. Because the kelyphitic garnet pseudomorphs are resistant to weathering, they tend to stick out in a conspicuous manner like 'rosary beads'.

In thin section, garnets $(0.3$ to $5 \mathrm{~mm})$ are round and surrounded by kelyphite rims 0.2 to $0.4 \mathrm{~mm}$ thick. Some kelyphite rims are concentrically zoned from dark inner zones to straw yellow outer zones. Many garnet grains are surrounded by a pyroxene-rich, equigranular mosaic (grain size, $\sim 0.2 \mathrm{~mm}$ ). Olivine and garnet are frequently observed in direct contact, however (Fig. 2). Small inclusions (0.1 to 0.4 $\mathrm{mm}$ ) of olivine, orthopyroxene, clinopyroxene, brown spinel, and sometimes of brown amphibole are commonly found in the garnet grains; but rutile inclusions, which are commonly observed in garnet grains from mafic layers, are absent. These inclusions are often found to have remained in the kelyphite pseudomorphs after the breakdown of garnets.

Garnet-bearing peridotites of similar texture to the Ronda ones occur in the Beni Bouchera peridotite, Morocco (Milliard, 1959). From textural observations, however, Kornprobst (1966) argued that the garnets at Beni Bouchera had been mechanically derived from garnet pyroxenite layers and that they were not in equilibrium with the host peridotites. This interpretation was also accepted for the Ronda peridotite (Dickey, 1970; Darot, 1973; Schubert, 1977). However, from the field and textural relations mentioned above and from the pyropic nature of the garnets, the author believes that garnet was stable in the peridotite before the 


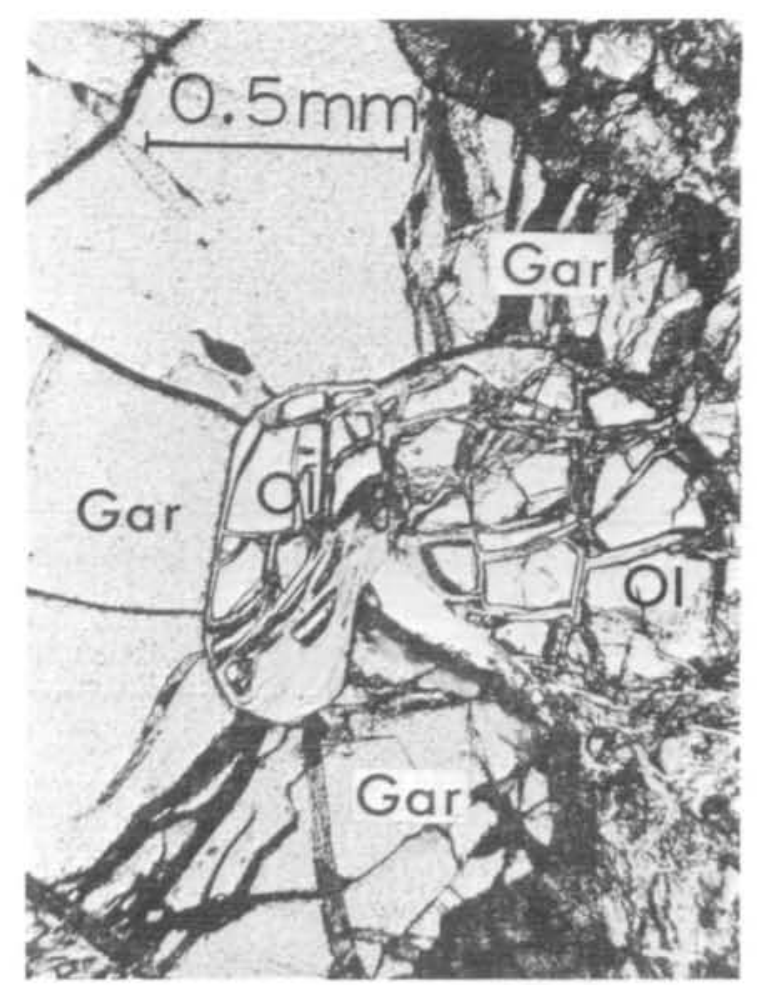

F1G. 2. Garnet/olivine contact. garnet peridotite $\mathrm{R} 501$. Gar = garnet; $\mathrm{Ol}=$ olivine.

kelyphitization of garnets. Thus, these (and perhaps also some part of the Beni Bouchera peridotite) can be called garnet peridotites belonging to the garnetlherzolite facies (see Mineral Facies and Zonal Mapping).

The possibility, however, cannot be ruled out that some garnet grains might have been derived from the garnet pyroxenite layers; but the point is that, even if this did happen, those garnets must have changed in their composition and modal abundances by reaction with the peridotite and, at high-enough pressures, have reached new chemical equilibria with olivine, pyroxene and $\mathrm{Cr}$-spinel. (If pressure were not high enough, the garnet would have reacted out by the reaction garnet + olivine $\rightarrow$ orthopyroxene + clinopyroxene + spinel.) In the multicomponent system, the spinel to garnet lherzolite transition is not univariant in $P-T$ space, and therefore, it is possible that garnet and $\mathrm{Cr}$-spinel coexist in the lherzolite assemblage over some pressure interval (MacGregor, 1970). Natural examples of spinel-garnet peridotite are reported from alpine-type peridotites (Lasnier, 1971; Rost \& Brenneis, 1978) and nodules in Australian kimberlite (Ferguson et al., 1975).

\section{MAFIC LAYERS}

Occurrences of mafic layers are well documented in Dickey (1970). Two types occur: (1) dark brown to gray layers, varying from garnet pyroxenites to olivine gabbros, and (2) bright green, chromian pyroxenite layers. The first type has been called 'magmatic-type' because these layers are similar in major element chemistry 
to some known basaltic to picritic magmas (Dickey, 1970). This chemical similarity, however, does not hold true in terms of trace elements, particularly rare earth elements (Dickey et al., 1978; Suen, 1978). The second type was once called 'tectonic-type' (Dickey, 1970), but here it is simply called 'chromian pyroxenite', avoiding any genetic connotation. Mineralogy is rather simple, either websterite or enstatitite, and is characterized by bright green, chromian diopside.

The abundance of the mafic layers is difficult to estimate accurately because the distribution of the layers is not uniform in the peridotite mass. Mafic layers are abundant in the northwest, but they are scarce or, in some places, absent in the south and the southeast (Fig. 3b). Overall, the average abundance is estimated to be about five volume per cent. Magmatic-type mafic layers are much more abundant than chromian pyroxenite layers.

In the field both types of layers appear as parallel, resistant bands of $1 \mathrm{~cm}$ to $3 \mathrm{~m}$ thickness. They are typically straight and concordant with the mineralogical banding of the peridotite; but locally, isoclinal folding has caused boudinage and lens structures. Some magmatic-type mafic layers are mineralogically inhomogeneous and banded; some have green chromian pyroxenite walls on either one side or both sides of the layers, suggesting that the chromian pyroxenite may be a reaction product between the magmatic-type layers and the peridotite host.

Examining some 1000 specimens, integrating old collections of Dickey (1969) into a new collection, the mineralogy of the mafic layers is organized into three mineralogical groups as follows, using throughout the abbreviations $\mathrm{Gar}=$ garnet, $\mathrm{Cpx}=$ clinopyroxene, Opx $=$ Orthopyroxene, Plag $=$ plagioclase, $\mathrm{Qz}=$ quartz, $\mathrm{Sp}=$ spinel, $\mathrm{Ol}=$ olivine, $\mathrm{Amph}=$ amphibole and Serp $=$ serpentine.

(1) Garnet pyroxenite group
(a) $\mathrm{Gar}+\mathrm{Cpx}+\mathrm{Plag}$
(b) $\mathrm{Gar}+\mathrm{Cpx}+\mathrm{Opx}$
(c) $\mathrm{Gar}+\mathrm{Cpx}$
(d) $\mathrm{Gar}+\mathrm{Cpx}+\mathrm{Plag}+\mathrm{Qz}$
(e) $\mathrm{Gar}+\mathrm{Cpx}+\mathrm{Opx}+$ green Sp (ceylonite)

(2) Spinel pyroxenite group
(a) $\mathrm{Cpx}+\mathrm{Opx}+$ green $\mathrm{Sp}$
(b) $\mathrm{Cpx}+\mathrm{Opx}+\mathrm{Plag}+$ green $\mathrm{Sp}$

(3) Olivine gabbro group

$\mathrm{Cpx}+\mathrm{Opx}+\mathrm{Plag}+\mathrm{Ol}+$ brown to opaque $\mathrm{Sp}$ (picotite to chromite)

Assemblages 1-b and 1-d were not observed by Dickey (1970). The assemblage Gar + Cpx + Plag + green Sp (Dickey, 1970, p. 34) was not confirmed. In each group mineral assemblages are listed in the order of decreasing abundance. Common accessory minerals are pale brown, pargasitic amphibole, rutile, ilmenite and sulfides. Graphite clots ( 1 to $2 \mathrm{~mm}$ size) occur in some garnet pyroxenite samples.

Many rocks reveal complex textures owing to incomplete subsolidus reactions, generally changing from assemblage groups 1 and 2 to 3 (Dickey, 1970; Schubert, 
1977). Only dominating mineral assemblages were considered in assigning each sample in the mineralogical categories above and were used as a data base for the mineralogical mapping.

\section{MINERAL FACIES AND ZONAL MAPPING}

From the petrographic observations it is evident that peridotite and mafic layers have undergone substantial recrystallization and metamorphism. Perhaps none of the rocks retain their original, igneous mineralogies, and the variation in mineralogy of the Ronda mass may be rigorously treated as a metamophic terrane in terms of bulk chemical composition and physical condition of crystallization. Figs. $3 a$ and $3 b$ show the geographical distribution of mineral assemblages from the Ronda peridotite and from the mafic layers (predominantly magmatic-type), respectively. The late stage, superficial recrystallization products such as kelyphite or symplectite are not considered here. Based on these field data, the peridotite

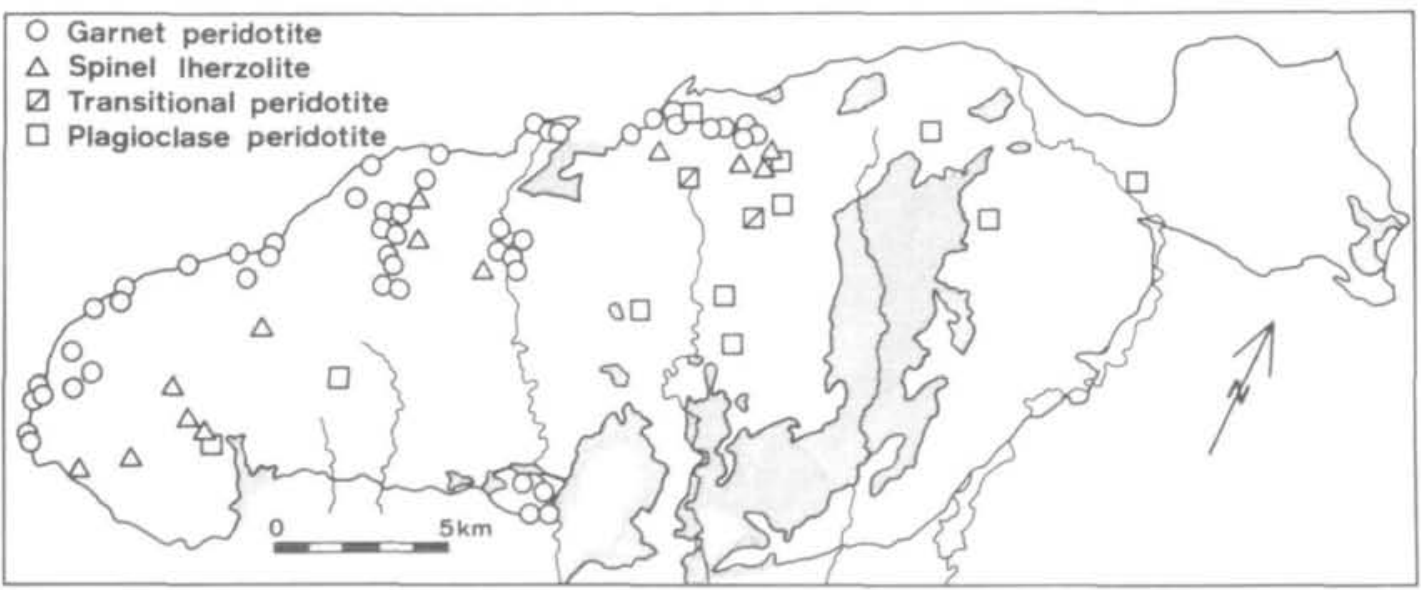

FIG. 3a. Regional distribution of the four mineralogical types of peridotite.

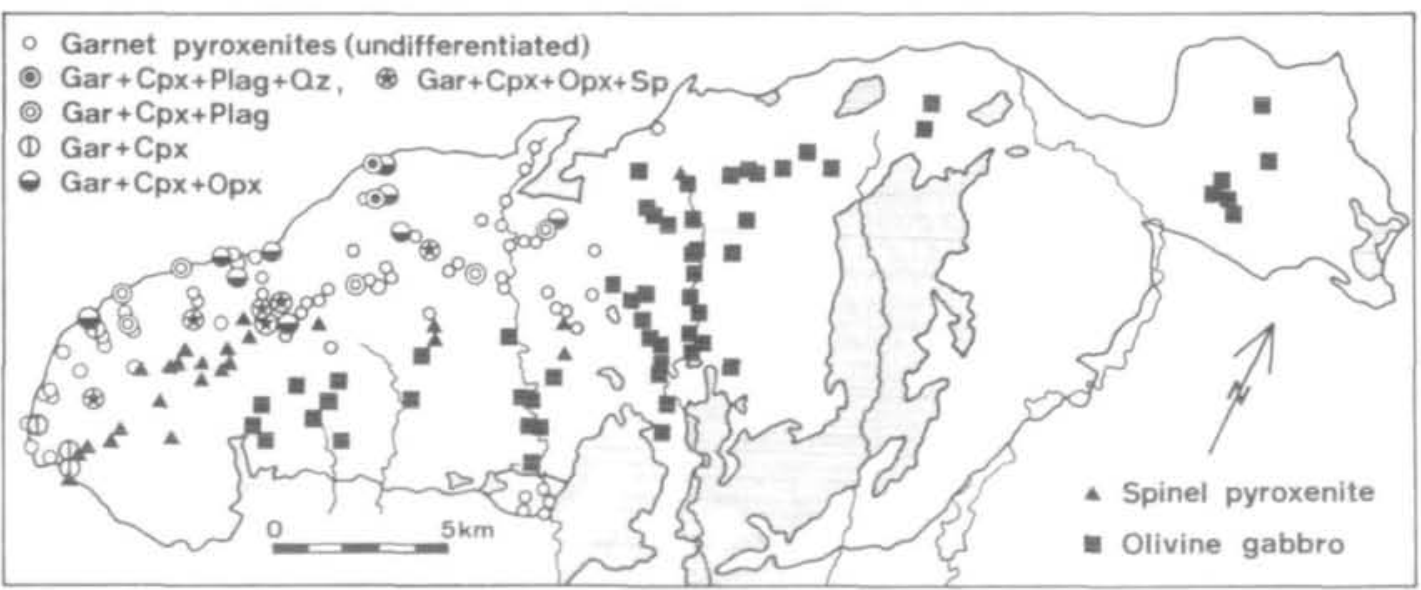




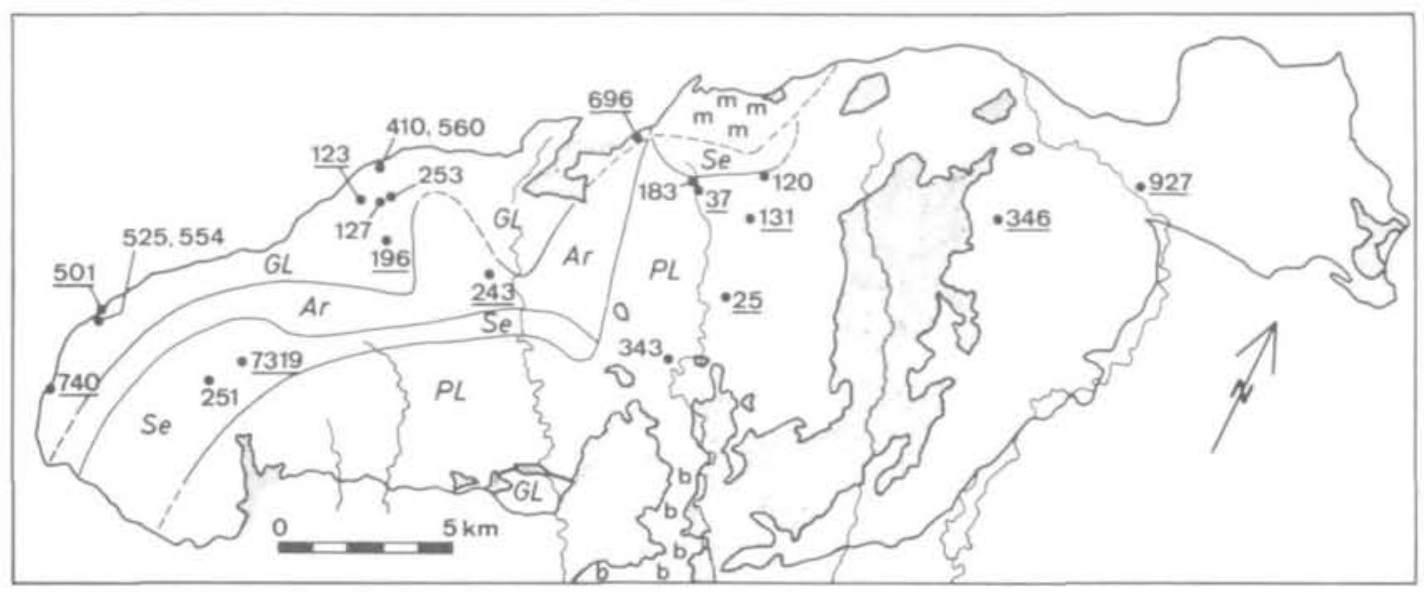

Fig. 3c. Mineral facies map derived from the data in Figs. $3 a$ and $3 b$, and sample locations of peridotite (underlined) and mafic layers (others). All sample numbers have prefix ' $R$ ' except ' 7319 ', that was provided by M. Lundeen. Mineral facies: $G L=$ garnet-lherzolite, $A r=$ ariégite, $S e=$ seiland, $P L=$ plagioclase-lherzolite. Dashed lines are inferred facies boundaries; $m=$ melange, $b=$ breccia of serpentine or serpentinized peridotite (Lundeen et al., 1979), stippled area = country rocks and tectonic inclusions of country rocks inside the peridotite.

terrane has been mapped into four mineral-facies zones (Fig. 3c): (1) garnetlherzolite facies, (2) ariégite subfacies of spinel-lherzolite facies, (3) seiland subfacies of spinel-lherzolite facies, and (4) plagioclase-lherzolite facies. The relationship of the mineral assemblages and the bulk rock compositions in each mineral facies may be easily visualized with the aid of a projection from diopside (chosen as a projection composition because it is a common phase in all rock types), onto the $\mathrm{CaAl}_{2} \mathrm{SiO}_{6}-\mathrm{SiO}_{2}-\mathrm{Mg}_{2} \mathrm{SiO}_{4}$ plane in the model system $\mathrm{CaO}-$ $\mathrm{MgO}-\mathrm{Al}_{2} \mathrm{O}_{3}-\mathrm{SiO}_{2}$ (Fig. 4). The garnet-lherzolite facies is defined by the stability of the forsterite-pyropic garnet assemblage; the ariegite subfacies, by the stability of pyropic garnet but without forsterite; the seiland subfacies, by the stability of spinel + enstatite + diopside and absence of garnet; the plagioclase-lherzolite facies, by the stability of forsterite + anorthite (O'Hara, 1967). The garnet-lherzolite facies and the ariégite subfacies may be further subdivided into subfacies of each, depending upon whether the anorthite + enstatite + diopside assemblage is stable (GLI for the former, $A r I$ for the latter) or the pyrope + quartz + diopside assemblage is stable ( $G L 2$ for the former, $A r 2$ for the latter) (see Fig. 4).

Starting from $G L 2$ there are two ways to arrive at $A r 1$. One way is to go from $G L 2$ to $A r 2$ by the reaction

$$
\text { garnet }+ \text { forsterite } \rightarrow \mathrm{Cpx}+\mathrm{Opx}+\text { spinel }
$$

and then from $A r 2$ to $A r l$ by the reaction

$$
\text { garnet }+ \text { quartz }+\mathrm{Cpx} \rightarrow \mathrm{Opx}+\text { anorthite }
$$

The other way to go is from $G L 2$ to $G L 1$ by reaction (2) first and then from GL1 to $A r l$ by reaction (1). The assemblage clinopyroxene + plagioclase + quartz has not been found in the spinel-lherzolite facies terrane (paragenesis $A r 2$ ), nor has 

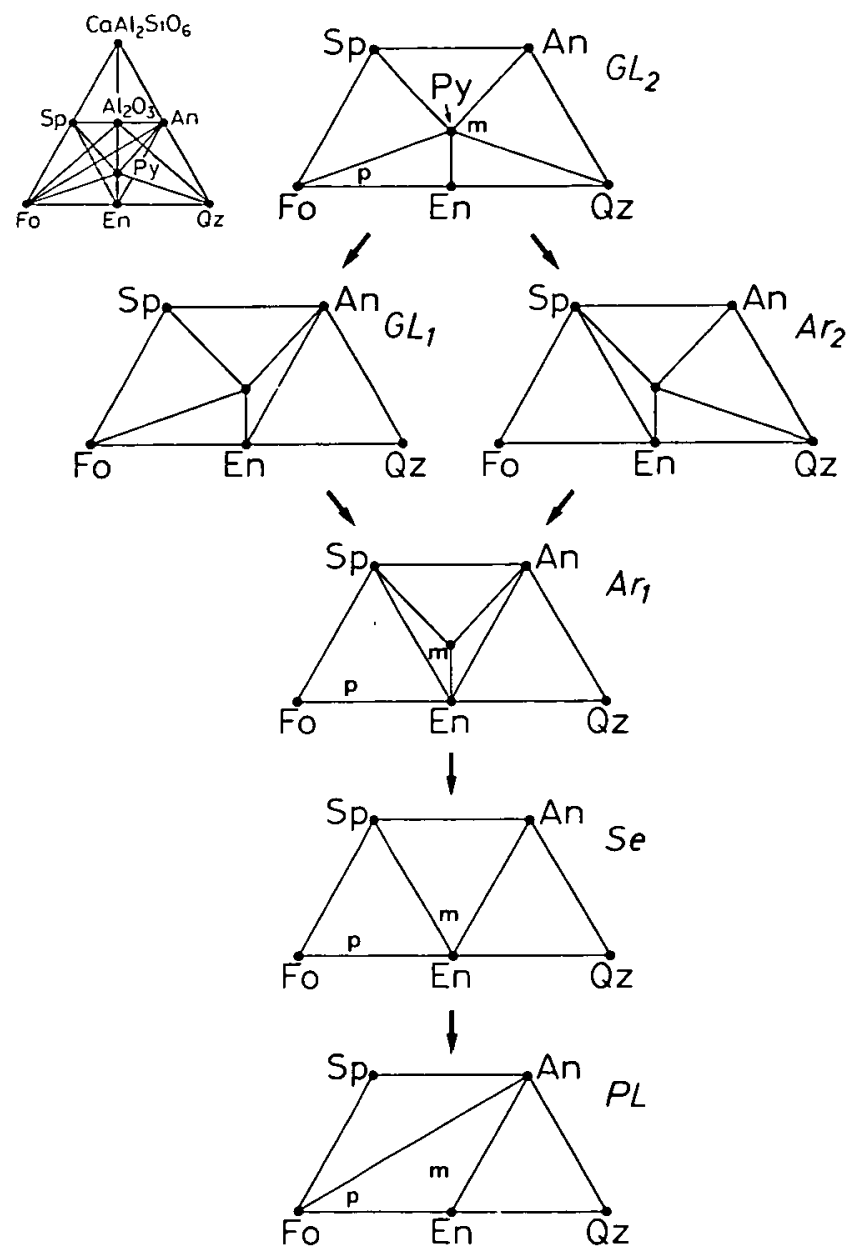

FIG. 4. Mineral paragenesis diagrams (in mole proportion) illustrating phase relations of the peridotite and mafic layers, $\mathrm{CaMgSi}_{2} \mathrm{O}_{6}, \mathrm{CaAl}_{2} \mathrm{SiO}_{4}, \mathrm{Mg}_{2} \mathrm{SiO}_{4}$ and $\mathrm{SiO}_{2}$ are chosen as componments in the $\mathrm{CaO}-$ $\mathrm{MgO}-\mathrm{Al}_{2} \mathrm{O}_{3}-\mathrm{SiO}_{2}$ system, and phases are projected from diopside $\left(\mathrm{CaMgSi}_{2} \mathrm{O}_{8}\right)$ onto the $\mathrm{CaAl}_{2} \mathrm{SiO}_{6}-$ $\mathrm{Mg}_{2} \mathrm{SiO}_{4}(\mathrm{Fo})-\mathrm{SiO}_{2}(\mathrm{Qz})$ plane. Chemographic relations are shown in upper left. $\mathrm{Sp}=$ spinel $\mathrm{MgA}_{2} \mathrm{O}_{4} . \mathrm{An}=$ anorthite $\mathrm{CaAl}_{2} \mathrm{Si}_{2} \mathrm{O}_{8}$. En = enstatite $\mathrm{MgSiO}_{3}$. $\mathrm{Py}=$ pyrope $\mathrm{Mg}_{3} \mathrm{Al}_{2} \mathrm{Si}_{3} \mathrm{O}_{12}$. Compositions of garnet and orthopyroxene solid solutions are approximated as Py and En, respectively for simplicity. Approximate compositions of peridotite and mafic layers are indicated by ' $\mathrm{p}$ ' and ' $\mathrm{m}$ ', respectively. See text for notations of facies names.

garnet + clinopyroxene + orthopyroxene + plagioclase been found in the garnet lherzolite. facies terrane (paragenesis $G L I$ ), probably because of the lack of appropriate bulk compositions. Therefore, which reaction occurs first, (1) or (2), remains indeterminate in the field.

Paragenesis $A r l$ may be transformed to $S e$ (seiland subfacies) by the breakdown of garnet:

$$
\text { garnet } \rightarrow \mathrm{Cpx}+\mathrm{Opx}+\text { anorthite }+ \text { spinel }
$$

Finally, Se may be transformed to $P L$ (plagioclase-lherzolite facies) by the reaction

$$
\mathrm{Cpx}+\mathrm{Opx}+\text { spinel } \rightarrow \text { anorthite }+ \text { forsterite }
$$


Reactions (1) to (4) have been experimentally studied in simple and multicomponent systems as summarized in Fig. 5, and it is well established that the four mineral facies $(G L, A r, S e, P L)$ are primarily manifestations of different pressures. Reaction boundaries (1a) and (2) in the $\mathrm{CaO}-\mathrm{MgO}-\mathrm{Al}_{2} \mathrm{O}_{3}-\mathrm{SiO}_{2}$ system cross each other in $P-T$ space (Fig. 5), so which reaction occurs first, (1) or (2), depends on temperature. However, by adding other components to the simple system, it is possible that reaction boundary (1) is displaced to higher pressures (1d for example), as discussed below, and does not intersect with reaction boundary (2) at all, in which case mineral facies $G L 1$ does not occur and the transitional between $G L 2$ and $A r 1$ is uniquely $A r 2$. Absence of index mineral assemblages for $A r 2$, for example, garnet + clinopyroxene + plagioclase + quartz in the spinel lherzolite terrane (see Fig. $3 b$ ) must still be explained by the lack of appropriate bulk compositions, however.

As is seen in Fig. $3 c$, the Ronda mass is clearly zoned from high-pressure facies in the northwest $(G L)$ to low-pressure facies in the southeast $(P L)$, but there are some irregularities. The zone of the seiland subfacies is missing in the middle part of the terrane, and it appears that the ariegite subfacies transforms directly to the

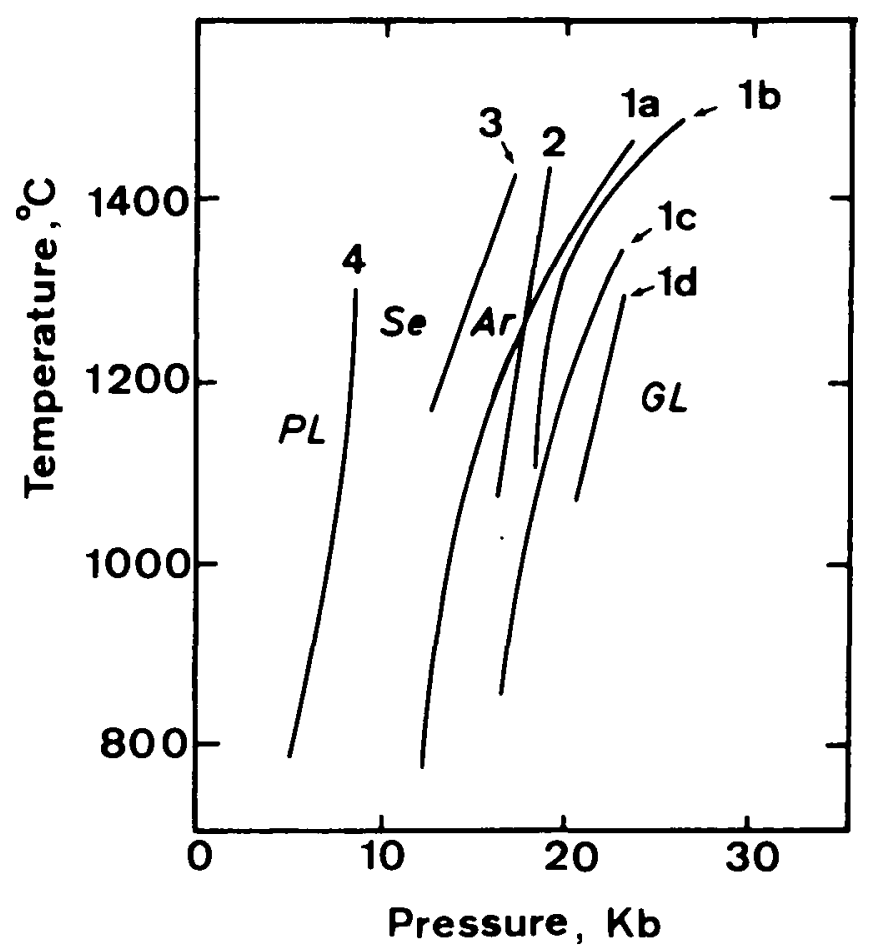

FIG. 5. $P-T$ phase diagram of mineral reactions (1), (2), (3) and (4) in text. There are four curves for reactions (1): (1a), Obata's (1976) theoretical interpretation of Kushiro \& Yoder's (1966) experimental data; (Ib), experimentally determined by O'Hara et al. (1971) in the $\mathrm{CaO}-\mathrm{MgO}-\mathrm{Al}_{2} \mathrm{O}_{3}-\mathrm{SiO}_{2}$ system; (1c), by the same authors in natural system; and (1d), experimentally determined by Green \& Ringwood (1967) for pyrolite III. (2) and (3) are from experimental data of Kushiro \& Yoder (1966). (4) is from thermodynamic calculations of Obata (1976). Appropriate $P-T$ fields for the garnet-lherzolite, ariegite, seiland and plagioclase-lherzolite facies are indicated by $G L, A r, S e$ and $P L$ respectively. 
plagioclase-lherzolite facies there. This region is close to a major structural discontinuity (Lundeen et al., 1979) and, therefore, a fault may separate the ariegite and plagioclase-lherzolite facies zones in this particular area. Local interfingering of the garnet-lherzolite and ariegite subfacies zones may indicate structural complexity that is not well understood in the field. In the southern part of the mass, a small area of the garnet-lherzolite facies is separated from the main part of the plagioclase-lherzolite facies by a steeply southward-dipping fault contact. Along the fault a $200 \mathrm{~m}$ thick, metasedimentary slab of cordierite-sillimanite gneiss occurs (see Fig. 3c). A small portion of the northern contact (' $\mathrm{m}$ ' in Fig. 3c) appears to be a mélange with several small $(<1 \mathrm{~km})$ tectonic blocks of peridotite of different mineral facies ( $G L, P L$ and possibly spinel-lherzolite facies). No mineral facies can be defined in peridotite breccia on the south of the terrane (' $b$ ' in Fig. $3 c$ ) because boulders of garnet pyroxenite and olivine gabbro are intermixed in a serpentine matrix. Apparently, the brecciation and sedimentary mixing postdate the metamorphic zonation of the peridotite mass. These late tectonic disturbances are, however, relatively minor, and the key observation is that the peridotite mass is regularly zoned from NW to SE in the sequence of garnet-lherzolite, ariégite, seiland and plagioclase-lherzolite facies.

Although this zonal structure may have resulted from pressure variations in the peridotite terrane during the metamorphism, the magnitude of pressure variation poses a problem. As is seen in Fig. 5, the $P-T$ field of the spinel-lherzolite facies ( $S L$ or $S e+A r$ ), which is bounded by reaction curves (4) and (1a) or (1b) in the simple system $\mathrm{CaO}-\mathrm{MgO}-\mathrm{Al}_{2} \mathrm{O}_{3}-\mathrm{SiO}_{2}$, has a minimum pressure width of about 6 $\mathrm{kb}$. This value may vary in natural, multicomponent systems because the position of the reaction boundaries may be affected by other components. Particularly important elements to be considered are $\mathrm{Cr}_{2} \mathrm{O}_{3}, \mathrm{Na}_{2} \mathrm{O}$ and $\mathrm{FeO} . \mathrm{Cr}_{2} \mathrm{O}_{3}$ stabilizes the spinel-lherzolite assemblages by shifting reaction boundary (4) to lower pressures and by shifting reaction boundary (1) to higher pressures (MacGregor, 1970). $\mathrm{Na}_{2} \mathrm{O}$, however, stabilizes the plagioclase-lherzolite assemblage relative to the spinel-lherzolite assemblage (Green \& Hibberson, 1970). FeO may stabilize the garnet-lherzolite assemblage relative to the spinel-lherzolite assemblage, but experimentally determined reaction boundaries between spinel- and garnetlherzolite facies in multicomponent systems are all located at higher pressures than those in the simple systems (see Fig. 5). Therefore, even when the effects of other components are considered, $6 \mathrm{~kb}$ is still the minimum pressure width of the spinel-lherzolite facies field.

In the field, the width of the spinel-lherzolite facies zone is $3 \mathrm{~km}$ or less, depending on the slope of the facies boundary surfaces in a three dimensional space. Obviously, this distance is too small to account for a $6 \mathrm{~kb}$ lithostatic pressure. This discrepancy between field observations and experimental data can be removed if we abandon the implicit assumption that the entire mass was metamorphosed at the same time. Perhaps, the peridotite was metamorphosed in one mineral facies at one time and later only part of it was re-metamorphosed to another facies. Certainly, polymetamorphism in the plagioclase-lherzolite facies occurred throughout the peridotite mass, as documented in the kelyphite and the 
breakdown products of aluminous pyroxenes, but these events postdate the main recrystallization that developed the zonal structure. A dynamic cooling model that may explain the zonal structure will be proposed in a later section.

\section{MINERAL CHEMISTRY}

Twelve peridotite samples representing a large area of the mass and all the important mineralogical variations (sample locations, Fig. $3 c$ ) were selected for detailed microprobe work. Coexisting pyroxenes, spinels, garnets, amphiboles and olivines were analyzed. Modal compositions and brief petrographic descriptions of these peridotites are listed in Table 1 .

All chemical analyses were made with the automated MAC electron microprobe at MIT and were reduced on-line with the 'GeoLab' program of Finger \& Hedidacos (1972) that employs the correction scheme of Albee \& Ray (1970). A filament voltage of $15 \mathrm{KV}$ was used with a beam current of $0.03 \mu \mathrm{A}$. Counting cutoffs for each element were set for 30 seconds or $30,000 \mathrm{cps}$, whichever came first. Both natural and synthetic material were used for standards (more detail in Obata, 1977).

\section{Pyroxenes}

Pyroxenes are quite variable in composition. They are zoned and exhibit large compositional variation even within a single thin section. Two textural types of pyroxene are distinguished: (a) pyroxene porphyroclasts and (b) pyroxene neoblasts.

(a) Pyroxene porphyroclasts. Pyroxene porphyroclasts are strongly zoned often in complex patterns. As an example, the $\mathrm{Al}_{2} \mathrm{O}_{3}$ content of an orthopyroxene porphyroclast in a transitional peridotite is illustrated in Fig. $6 . \mathrm{Al}_{2} \mathrm{O}_{3}$ ranges from $6.2 \mathrm{wt}$. per cent in the core to $2 \mathrm{wt}$. per cent at the rim. The zoning pattern is complicated by a decrease in $\mathrm{Al}_{2} \mathrm{O}_{3}$ around plagioclase lamellae and blebs, which are now altered to saussurite, and, to a lesser extent, around olivine and spinel inclusions. Near the periphery of the grain, the $\mathrm{Al}_{2} \mathrm{O}_{3}$ concentration gradient is less pronounced in the direction of elongation of the grain, which approximately coincides with the foliation of the peridotite. The gradients are very steep near the saussurite lamellae. Though not shown in Fig. $6, \mathrm{Cr}_{2} \mathrm{O}_{3}$ content is nearly constant ( $~ 0.6$ wt. per cent) throughout the grain except very near the grain margin, where it is slightly less. $\mathrm{Fe} / \mathrm{Mg}$ is nearly constant throughout the grain. This ratio is also constant between porphyroclasts and neoblasts in the same rock (compare Tables 2 and 3). It is important to note that, despite the complex zoning, there is an irregular but well defined area of a maximum and uniform $\mathrm{Al}_{2} \mathrm{O}_{3}$ content $(6.0$ to $6.2 \mathrm{wt}$. per cent) in the center of the grain away from the saussurite lamellae and from the spinel and olivine inclusions.

An interpretation of the pyroxene zoning is as follows. The pyroxenes were initially coarse-grained, homogeneous and thoroughly equilibrated in the peridotite. The peridotite was then deformed and recrystallized under different physical conditions at which the original aluminous enstatite was no longer stable. The original, large orthopyroxene grains were deformed, and new, small orthopyroxene 
TABLE 1

Petrographic data for analyzed peridotite samples

\begin{tabular}{|c|c|c|c|c|c|c|c|c|c|c|c|}
\hline \multirow[t]{2}{*}{ Sample } & \multicolumn{9}{|c|}{ Mode* and grain size } & \multirow{2}{*}{$\begin{array}{c}\text { Fo } \\
\text { mole } \\
\text { per cent }\end{array}$} & \multirow[b]{2}{*}{ Texture } \\
\hline & Ol & Serp & $O p x$ & $C p x$ & $S p$ & Gar & Plag & Amph & opaque & & \\
\hline R501 & $\begin{array}{c}40 \% \\
0.06-0.2 \mathrm{~mm}\end{array}$ & $31 \%$ & $\begin{array}{c}17 \% \\
0.1-0.2 \mathrm{~mm}\end{array}$ & $\begin{array}{c}2 \% \\
0.1-0.2 \mathrm{~mm}\end{array}$ & $\begin{array}{c}1 \% \\
0.7 \mathrm{~mm}\end{array}$ & $\begin{array}{c}7 \% \\
0.3-1.5 \mathrm{~mm}\end{array}$ & - & $\begin{array}{c}1 \% \\
0.1-0.2 \mathrm{~mm}\end{array}$ & $1.7 \%$ & $90 \cdot 1$ & $\begin{array}{l}\text { Cataclastic, weakly } \\
\text { foliated }\end{array}$ \\
\hline R 740 & $\begin{array}{c}58 \% \\
0.1-0.3 \mathrm{~mm}\end{array}$ & $18 \%$ & $\begin{array}{c}13 \% \\
0.1-10 \mathrm{~mm}\end{array}$ & $0.1-0.2 \mathrm{~mm}$ & $\begin{array}{c}1 \% \\
0.03-1 \mathrm{~mm}\end{array}$ & $\begin{array}{c}7 \% \\
0.4-4 \mathrm{~mm}\end{array}$ & - & $\begin{array}{c}1.3 \% \\
0.1-0.2 \mathrm{~mm}\end{array}$ & $1 \%$ & 90.6 & $\begin{array}{l}\text { Cataclastic, } \\
\text { moderately } \\
\text { foliated }\end{array}$ \\
\hline R696 & $\begin{array}{c}43 \% \\
0.1-1.5 \mathrm{~mm}\end{array}$ & $30 \%$ & $\begin{array}{c}13 \% \\
0.1-10 \mathrm{~mm}\end{array}$ & $\begin{array}{r}4.3 \% \\
0.1-1 \mathrm{~mm}\end{array}$ & $\begin{array}{c}1 \% \\
0.02-1 \mathrm{~mm}\end{array}$ & $\begin{array}{c}4 \% \\
0.2-2 \mathrm{~mm}\end{array}$ & - & $\begin{array}{c}1.3 \% \\
0.1-0.2 \mathrm{~mm}\end{array}$ & $3 \%$ & 89.4 & $\begin{array}{l}\text { Cataclastic, } \\
\text { moderately } \\
\text { foliated }\end{array}$ \\
\hline $\mathrm{R} 123$ & $\begin{array}{c}46 \% \\
0.2-2 \mathrm{~mm}\end{array}$ & $11 \%$ & $\begin{array}{c}18 \% \\
0.2-2 \mathrm{~mm}\end{array}$ & $\begin{array}{c}10 \% \\
0.4-1.5 \mathrm{~mm}\end{array}$ & $\begin{array}{c}0.6 \% \\
0.05-0.5 \mathrm{~mm}\end{array}$ & $\begin{array}{r}12 \cdot 3 \% \\
0 \cdot 4-3 \mathrm{~mm}\end{array}$ & - & $\begin{array}{c}1.8 \% \\
0.07-0.3 \mathrm{~mm}\end{array}$ & $1 \%$ & 87.8 & $\begin{array}{l}\text { Porphyroclastic, } \\
\text { moderately } \\
\text { foliated }\end{array}$ \\
\hline R196 & $\begin{array}{c}77 \% \\
0.2-2 \mathrm{~mm}\end{array}$ & $2 \%$ & $\begin{array}{c}16 \% \\
0.2-3 \mathrm{~mm}\end{array}$ & $\begin{array}{c}3 \% \\
0.4-1.2 \mathrm{~mm}\end{array}$ & $\begin{array}{c}1.7 \% \\
0.1-0.8 \mathrm{~mm}\end{array}$ & 一 & - & $\operatorname{tr}$ & $\operatorname{tr}$ & 90.6 & $\begin{array}{l}\text { Porphyroclastic, } \\
\text { moderately } \\
\text { foliated }\end{array}$ \\
\hline R243 & $\begin{array}{c}60 \% \\
2-3 \mathrm{~mm}\end{array}$ & $0 \%$ & $\begin{array}{c}23 \% \\
0.2-4 \mathrm{~mm}\end{array}$ & $\begin{array}{c}15 \% \\
0.1-0.8 \mathrm{~mm}\end{array}$ & $\begin{array}{c}3 \% \\
0.1-0.8 \mathrm{~mm}\end{array}$ & - & $\operatorname{tr}$ & $\operatorname{tr}$ & $\operatorname{tr}$ & 89.8 & Porphyroclastic \\
\hline 7319 & $\begin{array}{c}68 \% \\
1-7 \mathrm{~mm}\end{array}$ & $18 \%$ & $\begin{array}{c}12 \% \\
0.3-4 \mathrm{~mm}\end{array}$ & $\begin{array}{r}1.6 \% \\
0.4-1 \mathrm{~mm}\end{array}$ & $\begin{array}{c}1 \% \\
0.2-1.4 \mathrm{~mm}\end{array}$ & 一 & - & $\operatorname{tr}$ & $\mathrm{tr}$ & 91.7 & Coarse granular \\
\hline R37 & $\begin{array}{c}63 \% \\
0.1-4 \mathrm{~mm}\end{array}$ & $4 \%$ & $\begin{array}{c}26 \% \\
0.2-3 \mathrm{~mm}\end{array}$ & $\begin{array}{r}2 \cdot 5 \% \\
0.2-3 \mathrm{~mm}\end{array}$ & $\begin{array}{c}1 \% \\
0.1-1.5 \mathrm{~mm}\end{array}$ & - & $\begin{array}{r}3.7 \% \\
0.3 \mathrm{~mm}\end{array}$ & - & $\operatorname{tr}$ & 90.6 & $\begin{array}{l}\text { Porphyroclastic, } \\
\text { sheared and } \\
\text { annealed }\end{array}$ \\
\hline R131 & $\begin{array}{c}70 \% \\
0.2-1.6 \mathrm{~mm}\end{array}$ & $3 \%$ & $\begin{array}{c}17 \% \\
0.2-3 \mathrm{~mm}\end{array}$ & $\begin{array}{c}7 \% \\
0.2-7 \mathrm{~mm}\end{array}$ & $\begin{array}{r}0.2 \% \\
0.2-1 \mathrm{~mm}\end{array}$ & - & $\begin{array}{c}3 \% \\
0.3 \mathrm{~mm}\end{array}$ & $\operatorname{tr}$ & tr & 89.9 & $\begin{array}{l}\text { Porphyroclastic to } \\
\text { polygonal mosai }\end{array}$ \\
\hline R25 & $\begin{array}{c}61 \% \\
0.2-3 \mathrm{~mm}\end{array}$ & $15 \%$ & $\begin{array}{c}16 \% \\
0 \cdot 1-3 \mathrm{~mm}\end{array}$ & $\begin{array}{c}2.2 \% \\
0.4-1.5 \mathrm{~mm}\end{array}$ & $\begin{array}{c}1.3 \% \\
0.2-0.4 \mathrm{~mm}\end{array}$ & - & $\begin{array}{r}4.4 \% \\
0.3 \mathrm{~mm}\end{array}$ & - & $\operatorname{tr}$ & 90.7 & $\begin{array}{l}\text { Porphyroclastic to } \\
\text { xenomorphic } \\
\text { granular }\end{array}$ \\
\hline R346 & $\begin{array}{c}72 \% \\
0.8-1.7 \mathrm{~mm}\end{array}$ & $2 \%$ & $\begin{array}{c}16 \% \\
0 \cdot 2-3 \mathrm{~mm}\end{array}$ & $\begin{array}{c}1.6 \% \\
0.2-1.2 \mathrm{~mm}\end{array}$ & $\begin{array}{c}1 \% \\
0.3 \mathrm{~mm}\end{array}$ & - & $\begin{array}{r}7.8 \% \\
0.3 \mathrm{~mm}\end{array}$ & - & tr & 90.6 & $\begin{array}{l}\text { Porphyroclastic to } \\
\text { xenomorphic } \\
\text { granular }\end{array}$ \\
\hline R927 & $\begin{array}{c}59 \% \\
0.2-2 \mathrm{~mm}\end{array}$ & $20 \%$ & $\begin{array}{c}12 \% \\
0.2-2 \mathrm{~mm}\end{array}$ & $\begin{array}{c}0.7 \% \\
0.2-0.8 \mathrm{~mm}\end{array}$ & $\begin{array}{l}0.6 \% \\
0.3 \mathrm{~mm}\end{array}$ & - & $\begin{array}{r}6.9 \% \\
0.3 \mathrm{~mm}\end{array}$ & - & $\operatorname{tr}$ & 90.6 & $\begin{array}{l}\text { Porphyroclastic to } \\
\text { cataclastic }\end{array}$ \\
\hline
\end{tabular}

- 1500 to 2000 points were counted covering the entire area of standard-size thin sections. $\mathrm{tr}=$ trace (less than $\mathbf{0 . 2}$ per cent); Fo $=$ forsterite content of olivine, microprobe analyses.

R131 and R243 are new analyses of samples in Dickey (1970). 


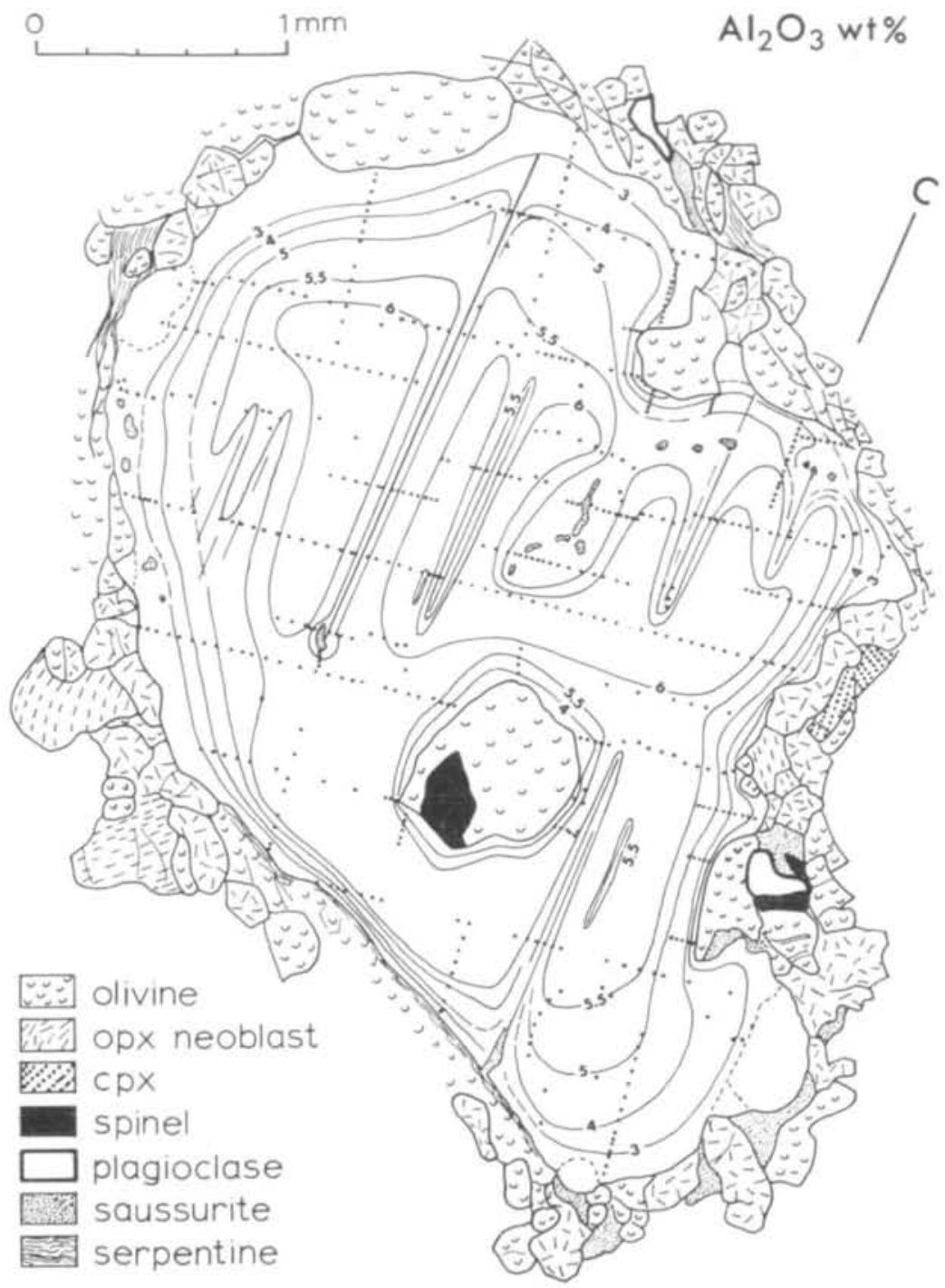

FIG. 6. $\mathrm{Al}_{2} \mathrm{O}_{3}$ contour map of an orthopyroxene porphyroclast in spinel-plagioclase transitional peridotite R37. Dots indicate analyzed points. Numerous clinopyroxene exsolution lamellae (omitted in the illustration) were avoided during the microprobe analyses by using a tightly-focused electron beam ( $\sim 2 \mu$ diameter). The $\mathrm{Al}_{2} \mathrm{O}_{3}$ content of the orthopyroxene neoblasts is between 2 and $3 \mathrm{wt}$. per cent. Direction of the crystallographic $c$-axis is indicated in upper right.

grains (neoblasts) formed either by nucleation and grain-growth or polygonization of the large grains. The neoblast compositions reflect the new physical conditions. Concomitantly, the porphyroclast composition was modified by diffusion processes including exsolution of diopside and perhaps of plagioclase. This interpretation implies that the high $\mathrm{Al}_{2} \mathrm{O}_{3}$ plateau retains the original orthopyroxene composition.

The bulk chemical composition of the high $\mathrm{Al}_{2} \mathrm{O}_{3}$ plateau, including the clinopyroxene lamellae, was obtained by averaging defocused beam (30 to $50 \mu$ diameter) microprobe analyses. This composition is called a primary composition 
in the sense that it represents the pyroxene composition when the pyroxenes were homogeneous and the peridotite was totally in equilibrium. Interestingly, the primary orthopyroxene compositions (Table 2) are similar although the peridotites are now of different mineral facies. For example, the primary $\mathrm{Al}_{2} \mathrm{O}_{3}$ contents are $6.3 \mathrm{wt}$. per cent in a garnet peridotite, 6.7 per cent in a spinel peridotite, and 6.2 per cent in a spinel-plagioclase transitional peridotite; the primary $\mathrm{CaO}$ contents are $1.21,1.4$ and 1.36 wt. per cent, respectively, for the same samples. This uniformity in primary orthopyroxene compositions indicates that prior to the last recrystallization and re-equilibration, the peridotites were homogeneous not just on a hand specimen scale but throughout the entire peridotite body.

Not all orthopyroxene porphyroclasts have $\mathrm{Al}_{2} \mathrm{O}_{3}$ plateaus. Those in plagioclase peridotites from the east part of the body do not retain their primary compositions, perhaps because of pervasive recrystallization and re-equilibration.

An attempt to obtain primary clinopyroxene compositions that could be paired with the primary orthopyroxene compositions failed because clinopyroxene porphyroclasts are scarce and tend to recrystallize more easily than orthopyroxenes, Fig. 7 illustrates a clinopyroxene grain in which $\mathrm{Al}_{2} \mathrm{O}_{3}$ varies from 7 to $3 \mathrm{wt}$. per cent and $\mathrm{Na}_{2} \mathrm{O}$ varies from 0.9 to 0.5 per cent. The compositional zoning has been disrupted by extensive precipitation of plagioclase and spinel from the aluminous pyroxene. No high $\mathrm{Al}_{2} \mathrm{O}_{3}$ plateau and thus no area of 'primary

T A B LE 2

Primary compositions of orthopyroxenes

\begin{tabular}{lccc}
\hline & $R I 23$ & $R 243$ & $R 37$ \\
\hline $\mathrm{SiO}_{2}$ & 52.90 & 53.0 & 53.5 \\
$\mathrm{TiO}_{2}$ & 0.22 & 0.14 & 0.06 \\
$\mathrm{Al}_{2} \mathrm{O}_{3}$ & 6.32 & 6.7 & 6.2 \\
$\mathrm{Cr}_{2} \mathrm{O}_{3}$ & 0.41 & 0.5 & 0.66 \\
$\mathrm{FeO}^{*}$ & 7.10 & 6.5 & 5.74 \\
$\mathrm{MnO}$ & 0.12 & 0.1 & 0.12 \\
$\mathrm{MgO}$ & 31.66 & 32.0 & 32.15 \\
$\mathrm{CaO}$ & 1.21 & 1.4 & 1.36 \\
$\mathrm{Na}{ }_{2} \mathrm{O}$ & 0.16 & n.d. & 0.10 \\
\hline TOTAL & 100.00 & 100.3 & 99.89 \\
\hline & & & \\
& Cations per 6 & oxygens & \\
\hline $\mathrm{Si}$ & 1.840 & 1.834 & 1.853 \\
$\mathrm{Ti}$ & 0.006 & 0.004 & 0.002 \\
$\mathrm{Al}$ & 0.259 & 0.273 & 0.253 \\
$\mathrm{Cr}$ & 0.011 & 0.014 & 0.018 \\
$\mathrm{Fe}$ & 0.207 & 0.188 & 0.166 \\
$\mathrm{Mn}$ & 0.004 & 0.003 & 0.004 \\
$\mathrm{Mg}$ & 1.641 & 1.651 & 1.660 \\
$\mathrm{Ca}$ & 0.045 & 0.052 & 0.050 \\
$\mathrm{Na}$ & 0.011 & n.d. & 0.007 \\
\hline TOTAL & 4.024 & 4.019 & 4.013 \\
\hline
\end{tabular}

* Total $\mathrm{Fe}$ as $\mathrm{FeO}$; n.d. = not determined. 

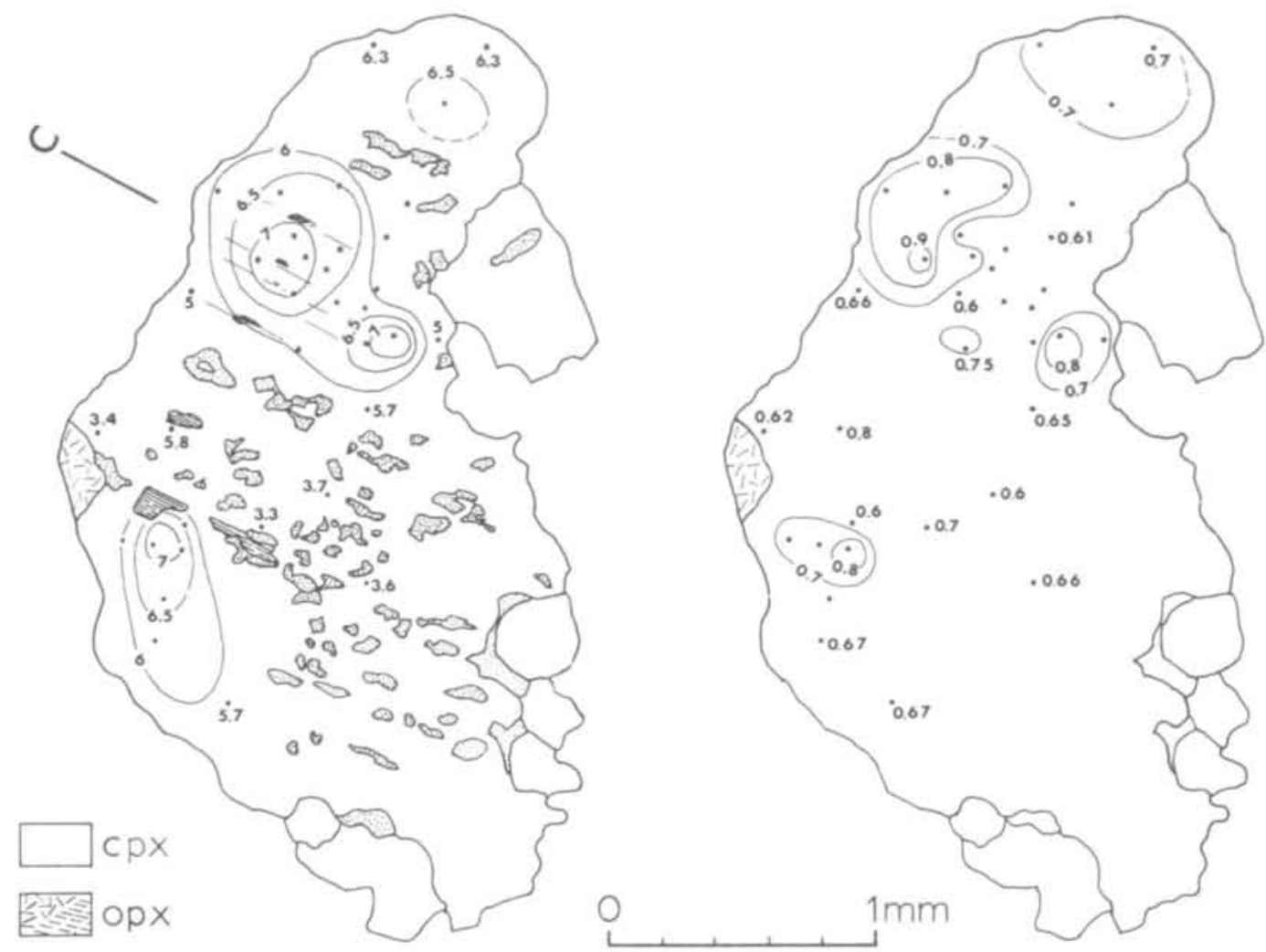

saussurite

+ spinel

$$
\mathrm{Al}_{2} \mathrm{O}_{3} \mathrm{w}+\%
$$

$\mathrm{Na}_{2} \mathrm{O} w+\%$

FIG. 7. $\mathrm{Al}_{2} \mathrm{O}_{3}$ contour map (left) and $\mathrm{Na}_{2} \mathrm{O}$ contour map (right) of a clinopyroxene porphyroclast in sample R37. Exsolution lamellae of orthopyroxene are coarser and more widely spaced than those of clinopyroxene in orthopyroxene porphyroclasts. Only the largest blebs of orthopyroxene and saussurite are illustrated. Direction of the crystallographic $c$-axis is indicated in upper left.

composition' is found. The $\mathrm{CaO}$ content is remarkably constant ( 21 to 22 wt. per cent) throughout the grain. An attempt to determine the $\mathrm{CaO}$ distribution prior to orthopyroxene exsolution was hampered because orthopyroxene lamellae are coarse $(\sim 20 \mu)$ and not evenly distributed throughout the grain.

(b) Pyroxene neoblasts. Pyroxene neoblasts are also chemically inhomogeneous, but they define rather narrow compositional ranges distinct from those of pyroxene porphyroclasts. The neoblasts are also zoned to a variable extent, and considerable grain-to-grain inhomogeneities are seen in spinel and transitional peridotites. On the average, however, in contrast to the uniformity of pyroxene neoblasts, there is a good correlation between chemistry and the metamorphic grade (Fig. 8). Average core compositions of the pyroxene neoblasts are listed in Table 3.

The $\mathrm{Al}_{2} \mathrm{O}_{3}$ content of orthopyroxene neoblasts is highest in spinel peridotites ( 4 to 5 wt. per cent) and decreases down to 3 wt. per cent in garnet peridotites and 2 wt. per cent in plagioclase peridotites. The $\mathrm{Al}_{2} \mathrm{O}_{3}$ content of clinopyroxene neoblasts generally parallels that of orthopyroxene neoblasts and the $\mathrm{Al} /(\mathrm{Al}+\mathrm{Cr})$ 

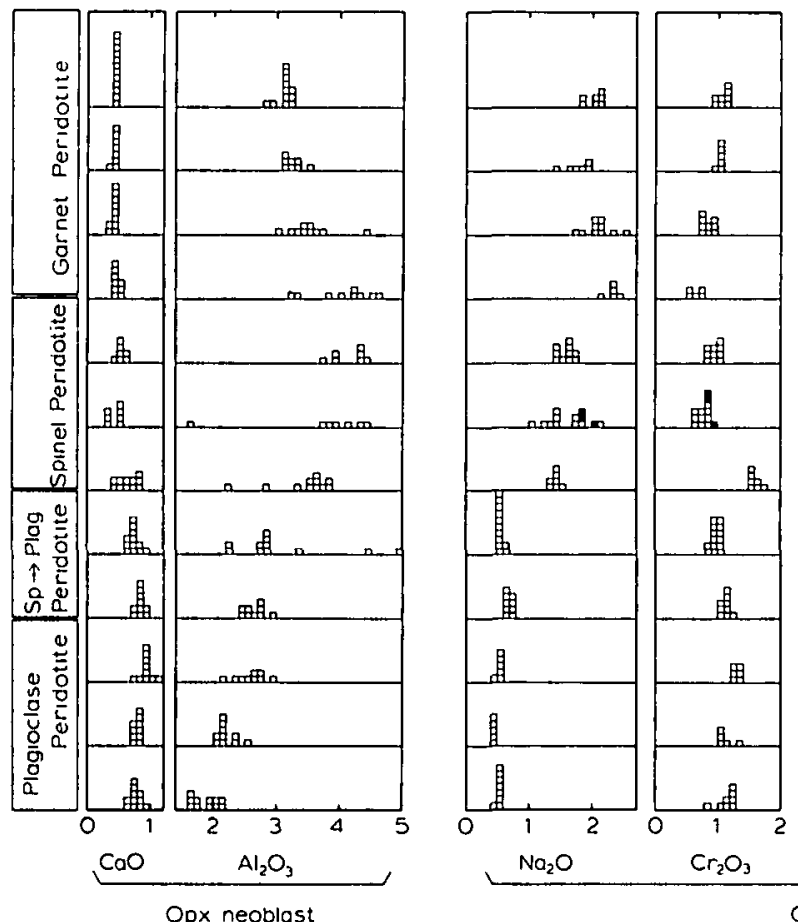

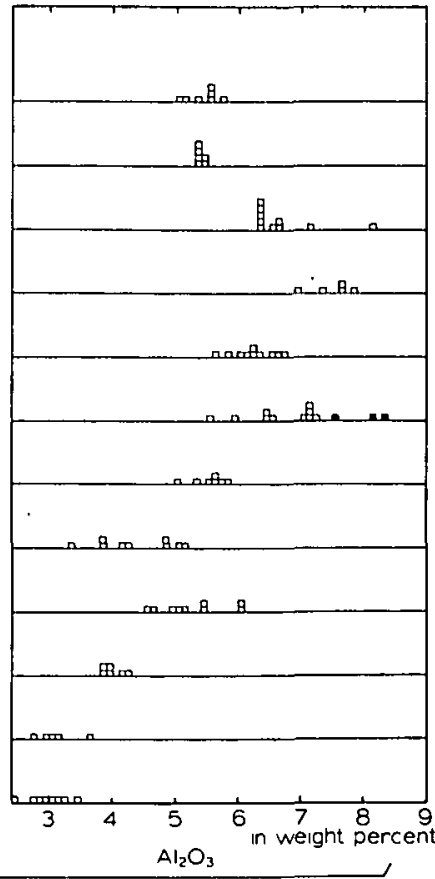

Cpx neoblast

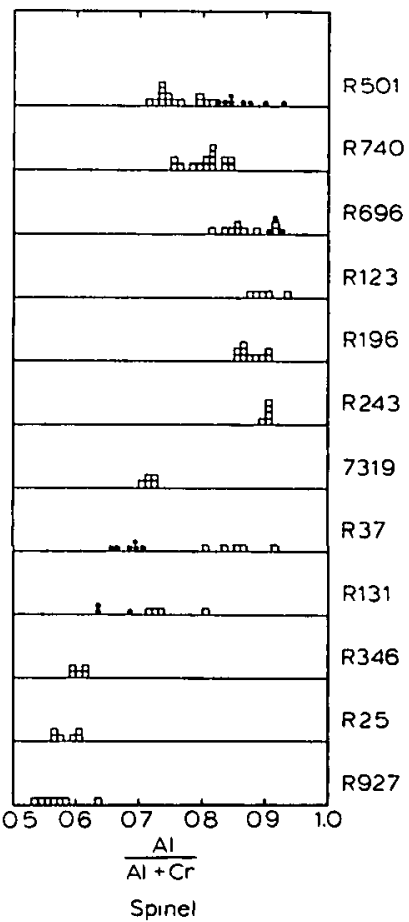

FIG. 8. Summary of core compositions of pyroxene neoblasts and coexisting spinels from 12 peridotites. Each symbol represents an average of three to six analyses in the core of one grain. Solid squares for sample R243 indicate 'turbid' clinopyroxenes. Solid circles for spinels from samples R501 and R696 are 'tiny' grains, and those for R37 and R131 are small grains surrounded by plagioclase. 
TABLE 3

Average analyses of cores of pyroxene neoblasts

\begin{tabular}{|c|c|c|c|c|c|c|c|c|c|c|c|c|c|}
\hline & \multicolumn{2}{|c|}{ R50I } & \multicolumn{2}{|c|}{$R 740$} & \multicolumn{2}{|c|}{$R 696$} & \multicolumn{2}{|c|}{$\cdot R 123$} & \multicolumn{2}{|c|}{$R 196$} & \multicolumn{3}{|c|}{$R 243$} \\
\hline & $O p x$ & $C p x$ & $O p x$ & $C p x$ & $O p x$ & $C p x$ & $O p x$ & $C p x$ & $O_{p x}$ & $C p x$ & $O p x$ & $C p x$ & $C p x-\mathrm{t}$ \\
\hline $\mathrm{SiO}_{2}$ & 55.67 & $53 \cdot 25$ & $55 \cdot 26$ & 52.79 & 54.86 & $52 \cdot 36$ & 54.91 & 51.84 & $55 \cdot 14$ & 51.81 & 54.64 & 51.60 & $52 \cdot 24$ \\
\hline $\mathrm{TiO}_{2}$ & 0.07 & 0.50 & 0.12 & 0.46 & 0.14 & 0.85 & 0.17 & 1.08 & 0.08 & 0.44 & 0.10 & 0.55 & 0.53 \\
\hline $\mathrm{Al}_{2} \mathrm{O}_{3}$ & $3 \cdot 13$ & 5.40 & 3.28 & $5 \cdot 38$ & 3.43 & $6 \cdot 52$ & 4.06 & 7.49 & $4 \cdot 19$ & $6 \cdot 25$ & 4.04 & $6 \cdot 84$ & 8.00 \\
\hline $\mathrm{Cr}_{2} \mathrm{O}_{3}$ & 0.35 & 1.07 & 0.33 & 1.03 & 0.28 & 0.83 & 0.28 & 0.64 & 0.47 & 0.95 & 0.29 & 0.75 & 0.89 \\
\hline $\mathrm{FeO}^{*}$ & 6.55 & 2.51 & 6.69 & 2.48 & 7.43 & 2.78 & 7.48 & 3.07 & $6 \cdot 26$ & 2.41 & 6.84 & 2.87 & $3 \cdot 11$ \\
\hline $\mathrm{MnO}$ & 0.15 & 0.08 & 0.17 & 0.09 & 0.17 & 0.05 & 0.09 & 0.10 & 0.18 & 0.10 & 0.16 & 0.13 & 0.12 \\
\hline $\mathrm{MgO}$ & 34.00 & $15 \cdot 58$ & $34 \cdot 15$ & $15 \cdot 87$ & 33.64 & $14 \cdot 72$ & $33 \cdot 17$ & $14 \cdot 27$ & 33.65 & 15.09 & $34 \cdot 38$ & $15 \cdot 20$ & 15.74 \\
\hline $\mathrm{CaO}$ & 0.44 & 19.87 & 0.43 & $20 \cdot 86$ & 0.43 & 20.08 & 0.47 & 19.77 & 0.56 & 20.81 & 0.48 & 20.40 & 18.86 \\
\hline $\mathrm{Na}_{2} \mathrm{O}$ & 0.05 & 2.04 & n.d. & 1.75 & n.d. & 2.07 & 0.06 & $2 \cdot 32$ & n.d. & 1.58 & n.d. & 1.55 & 1.92 \\
\hline 'TOTAL & 100.41 & $100 \cdot 30$ & $100 \cdot 43$ & $100 \cdot 71$ & $100 \cdot 38$ & $100 \cdot 26$ & $100 \cdot 69$ & $100 \cdot 58$ & 100.53 & 99.44 & 100.93 & 99.89 & 101.41 \\
\hline \multicolumn{14}{|c|}{ Cations per 6 oxygens } \\
\hline $\mathrm{Si}$ & 1.918 & 1.916 & 1.906 & 1.898 & 1.900 & 1.889 & 1.894 & 1.866 & 1.896 & 1.885 & 1.878 & 1.870 & 1.858 \\
\hline $\mathrm{Ti}$ & 0.002 & 0.014 & 0.003 & 0.012 & 0.004 & 0.023 & 0.004 & 0.029 & 0.002 & 0.012 & 0.003 & 0.015 & 0.014 \\
\hline Al & 0.127 & 0.229 & 0.133 & 0.228 & 0.140 & 0.277 & 0.165 & $0: 318$ & 0.170 & 0.268 & 0.164 & 0.292 & 0.335 \\
\hline $\mathrm{Cr}$ & 0.010 & 0.030 & 0.009 & 0.029 & 0.008 & 0.024 & 0.008 & 0.018 & 0.013 & 0.027 & 0.008 & 0.021 & 0.025 \\
\hline $\mathrm{Fe}$ & 0.189 & 0.076 & 0.193 & 0.075 & 0.215 & 0.084 & 0.216 & 0.092 & 0.180 & 0.073 & 0.197 & 0.087 & 0.093 \\
\hline $\mathrm{Mn}$ & 0.004 & 0.002 & 0.005 & 0.003 & 0.005 & 0.002 & 0.003 & 0.003 & 0.005 & 0.003 & 0.005 & 0.004 & 0.004 \\
\hline $\mathrm{Mg}$ & 1.745 & 0.836 & 1.755 & 0.850 & 1.736 & 0.791 & 1.705 & 0.766 & 1.724 & 0.818 & 1.761 & 0.821 & 0.834 \\
\hline $\mathrm{Ca}$ & 0.016 & 0.766 & 0.016 & 0.804 & 0.016 & 0.776 & 0.017 & 0.763 & 0.021 & 0.811 & 0.018 & 0.792 & 0.719 \\
\hline $\mathrm{Na}$ & 0.003 & 0.142 & n.d. & 0.122 & n.d. & 0.145 & 0.004 & 0.162 & n.d. & 0.111 & n.d. & 0.109 & 0.132 \\
\hline TOTAL & 4.014 & 4.012 & 4.020 & 4.022 & 4.023 & 4.010 & 4.017 & 4.017 & 4.011 & 4.011 & 4.033 & 4.012 & 4.014 \\
\hline
\end{tabular}


TABLE 3 (continued)

\begin{tabular}{|c|c|c|c|c|c|c|c|c|c|c|c|c|}
\hline & \multicolumn{2}{|c|}{7319} & \multicolumn{2}{|c|}{$R 37$} & \multicolumn{2}{|c|}{$R 131$} & \multicolumn{2}{|c|}{$R 25$} & \multicolumn{2}{|c|}{$R 346$} & \multicolumn{2}{|c|}{$R 927$} \\
\hline & $O p x$ & $C p x$ & $O p x$ & $C p x$ & $O p x$ & $C p x$ & $O p x$ & $C p x$ & $O p x$ & $C p x$ & $O p x$ & $C p x$ \\
\hline $\begin{array}{l}\mathrm{SiO}_{2} \\
\mathrm{TiO}_{2} \\
\mathrm{Al}_{2} \mathrm{O}_{3} \\
\mathrm{Cr}_{2} \mathrm{O}_{3} \\
\mathrm{FeO}^{*} \\
\mathrm{MnO} \\
\mathrm{MgO} \\
\mathrm{CaO} \\
\mathrm{Na}_{2} \mathrm{O}\end{array}$ & $\begin{array}{r}54.56 \\
0.07 \\
3.69 \\
0.67 \\
5.61 \\
0.14 \\
35.54 \\
0.74 \\
\text { n.d. }\end{array}$ & $\begin{array}{r}52.18 \\
0.33 \\
5.54 \\
1.61 \\
2.41 \\
0.10 \\
15.66 \\
21.01 \\
1.41\end{array}$ & $\begin{array}{r}56.24 \\
0.09 \\
2.63 \\
0.54 \\
6.13 \\
0.15 \\
34.14 \\
0.74 \\
0.03\end{array}$ & $\begin{array}{r}51.88 \\
0.34 \\
4.19 \\
1.00 \\
2.46 \\
0.08 \\
16.62 \\
22.81 \\
0.56\end{array}$ & $\begin{array}{r}55.73 \\
0.43 \\
2.63 \\
0.48 \\
6.79 \\
0.13 \\
33.54 \\
0.82 \\
0.02\end{array}$ & $\begin{array}{r}50.19 \\
1.44 \\
5.32 \\
1.12 \\
3.07 \\
0.11 \\
16.29 \\
21.91 \\
0.70\end{array}$ & $\begin{array}{r}55.93 \\
0.08 \\
2.22 \\
0.51 \\
6.30 \\
0.15 \\
34.84 \\
0.77 \\
\text { n.d. }\end{array}$ & $\begin{array}{r}53.10 \\
0.31 \\
3 \cdot 10 \\
1.09 \\
2.68 \\
0.12 \\
17.95 \\
21.37 \\
0.42\end{array}$ & $\begin{array}{r}55.54 \\
0.17 \\
2.55 \\
0.55 \\
6.42 \\
0.15 \\
34.58 \\
0.89 \\
\text { n.d. }\end{array}$ & $\begin{array}{r}52.47 \\
0.32 \\
4.01 \\
1.27 \\
2.56 \\
0.06 \\
17.18 \\
21.57 \\
0.52\end{array}$ & $\begin{array}{r}56.18 \\
0.11 \\
1.86 \\
0.46 \\
6.20 \\
0.13 \\
35.06 \\
0.76 \\
\text { n.d. }\end{array}$ & $\begin{array}{r}52.16 \\
0.38 \\
2.98 \\
1.16 \\
2.49 \\
0.09 \\
17.31 \\
22.78 \\
0.53\end{array}$ \\
\hline TOTAL & $100 \cdot 02$ & $100 \cdot 25$ & $100 \cdot 69$ & 99.94 & $100 \cdot 57$ & $100 \cdot 15$ & $100 \cdot 80$ & $100 \cdot 14$ & $100 \cdot 85$ & 99.96 & $100 \cdot 76$ & 99.88 \\
\hline \multicolumn{13}{|c|}{ Cations per 6 oxygens } \\
\hline $\begin{array}{l}\mathrm{Si} \\
\mathrm{Ti} \\
\mathrm{Al} \\
\mathrm{Cr} \\
\mathrm{Fe} \\
\mathrm{Mn} \\
\mathrm{Mg} \\
\mathrm{Ca} \\
\mathrm{Na}\end{array}$ & $\begin{array}{c}1.885 \\
0.002 \\
0.150 \\
0.018 \\
0.162 \\
0.004 \\
1.779 \\
0.027 \\
\text { n.d. }\end{array}$ & $\begin{array}{l}1.887 \\
0.009 \\
0.236 \\
0.046 \\
0.073 \\
0.003 \\
0.844 \\
0.814 \\
0.099\end{array}$ & $\begin{array}{l}1.930 \\
0.002 \\
0.106 \\
0.015 \\
0.176 \\
0.004 \\
1.746 \\
0.027 \\
0.002\end{array}$ & $\begin{array}{l}1.889 \\
0.009 \\
0.180 \\
0.029 \\
0.075 \\
0.002 \\
0.902 \\
0.890 \\
0.040\end{array}$ & $\begin{array}{l}1.922 \\
0.011 \\
0.107 \\
0.013 \\
0.196 \\
0.004 \\
1.724 \\
0.030 \\
0.001\end{array}$ & $\begin{array}{l}1.832 \\
0.040 \\
0.229 \\
0.032 \\
0.094 \\
0.003 \\
0.886 \\
0.857 \\
0.050\end{array}$ & $\begin{array}{c}1.921 \\
0.002 \\
0.090 \\
0.014 \\
0.181 \\
0.004 \\
1.784 \\
0.028 \\
\text { n.d. }\end{array}$ & $\begin{array}{l}1.921 \\
0.008 \\
0.132 \\
0.031 \\
0.081 \\
0.004 \\
0.968 \\
0.828 \\
0.029\end{array}$ & $\begin{array}{c}1.910 \\
0.004 \\
0.103 \\
0.015 \\
0.185 \\
0.004 \\
1.772 \\
0.033 \\
\text { n.d. }\end{array}$ & $\begin{array}{l}1.903 \\
0.009 \\
0.171 \\
0.036 \\
0.078 \\
0.002 \\
0.929 \\
0.838 \\
0.037\end{array}$ & $\begin{array}{c}1.929 \\
0.003 \\
0.075 \\
0.012 \\
0.178 \\
0.004 \\
1.794 \\
0.028 \\
\text { n.d. }\end{array}$ & $\begin{array}{l}1.903 \\
0.010 \\
0.128 \\
0.033 \\
0.076 \\
0.003 \\
0.941 \\
0.891 \\
0.038\end{array}$ \\
\hline TOTAL & $4 \cdot 028$ & 4.012 & 4.008 & 4.017 & 4.008 & 4.023 & 4.025 & 4.003 & 4.027 & 4.003 & 4.024 & 4.024 \\
\hline
\end{tabular}

Total $\mathrm{Fe}$ as $\mathrm{FeO}$.

Cpx-t: Average analysis of 'turbid' clinopyroxene. 
ratio of coexisting spinel (see below). The $\mathrm{CaO}$ content of orthopyroxene neoblasts increases monotonically from $0.4 \mathrm{wt}$. per cent in garnet peridotites up to $0.9 \mathrm{wt}$. per cent in plagioclase peridotites. $\mathrm{Na}_{2} \mathrm{O}$ in clinopyroxene is highest in garnet peridotites ( $\sim 2 \mathrm{wt}$. per cent) and is reduced in plagioclase peridotite $(\sim 0.5 \mathrm{wt}$. per cent), in which $\mathrm{Na}$ is incorporated in the plagioclase phase.

Some details of chemical zoning are illustrated in Fig. 9, in terms of the $\mathrm{Al}_{2} \mathrm{O}_{3}-\mathrm{CaO}$ diagram for orthopyroxene neoblasts and the $\mathrm{Al}_{2} \mathrm{O}_{3}-\mathrm{Na}_{2} \mathrm{O}$ diagram for clinopyroxene neoblasts. Pyroxene neoblasts from spinel and transitional peridotites are strongly zoned from $\mathrm{Al}$-rich cores to $\mathrm{Al}$-poor rims. In orthopyroxene neoblasts the $\mathrm{CaO}$ content decreases slightly toward the rims. Neoblasts from plagioclase peridotites are more homogeneous although the same zoning pattern is observed as in those from spinel peridotites. The $\mathrm{Al}$-zoning pattern is reversed in some garnet peridotite samples (R501, R740), that is, both ortho- and clinopyroxene neoblasts are moderately zoned from $\mathrm{Al}$-poor cores to Al-rich rims, particularly strongly in pyroxene grains next to garnet grains. The $\mathrm{CaO}$ content is, however, constant across the orthopyroxene neoblasts. In clinopyroxene neoblasts from garnet and spinel peridotites, $\mathrm{Na}_{2} \mathrm{O}$ and $\mathrm{Al}_{2} \mathrm{O}_{3}$ decrease toward the rims. The decrease in $\mathrm{Na}_{2} \mathrm{O}$ is possibly due to element re-partitioning at the stage of secondary amphibole formation.

The unusual 'turbid' clinopyroxene grains $(0.2$ to $1.5 \mathrm{~mm}$ in size $)$ in spinel lherzolite R243 (see Petrography) were analyzed with a defocused electron beam (30 $\mu$ diameter) (Cpx-t in Table 3). These turbid grains are distinctly more aluminous and less calcic than the smaller, clean clinopyroxene grains in the same thin section, and they are thought to be relicts of early, high-temperature pyroxenes. The smaller, clean clinopyroxene grains are considered to be in equilibrium with the orthopyroxene neoblasts.

As is apparent from the zoning, the neoblast compositions have also been partly modified by solid state diffusion. The core compositions of the neoblasts were assumed to represent the initial neoblast compositions (i.e. at the stage of the neoblast nucleation and growth).

\section{Spinel}

Spinels span a wide range of composition and, as is also true for pyroxenes, good correlations are observed between chemistry, texture, and metamorphic grade. Average spinel analyses are listed in Table 4 . In general, the $\mathrm{Al} / \mathrm{Cr}$ ratios are, as expected, largest in spinel peridotites (except 7319, a depleted harzburgite; see mode in Table 1) and are less in garnet and plagioclase peridotites (Fig. 8).

Chemical inhomogeneities are particularly pronounced in garnet and transitional peridotites. Grains are zoned from aluminous cores to chromiferous rims in spinel peridotites (except some grains in R196) and in transitional and plagioclase peridotites. In transitional peridotites large grains are zoned from very aluminous cores to chromiferous rims; small grains $(0.1$ to $0.2 \mathrm{~mm})$, typically surrounded by plagioclase, are distinctly more chromiferous. Analogous to the pyroxene neoblasts, the zoning pattern of spinel is reversed in garnet peridotites. That is, the composition of medium-grained spinels $(\sim 0.5 \mathrm{~mm})$ is fairly constant except near 

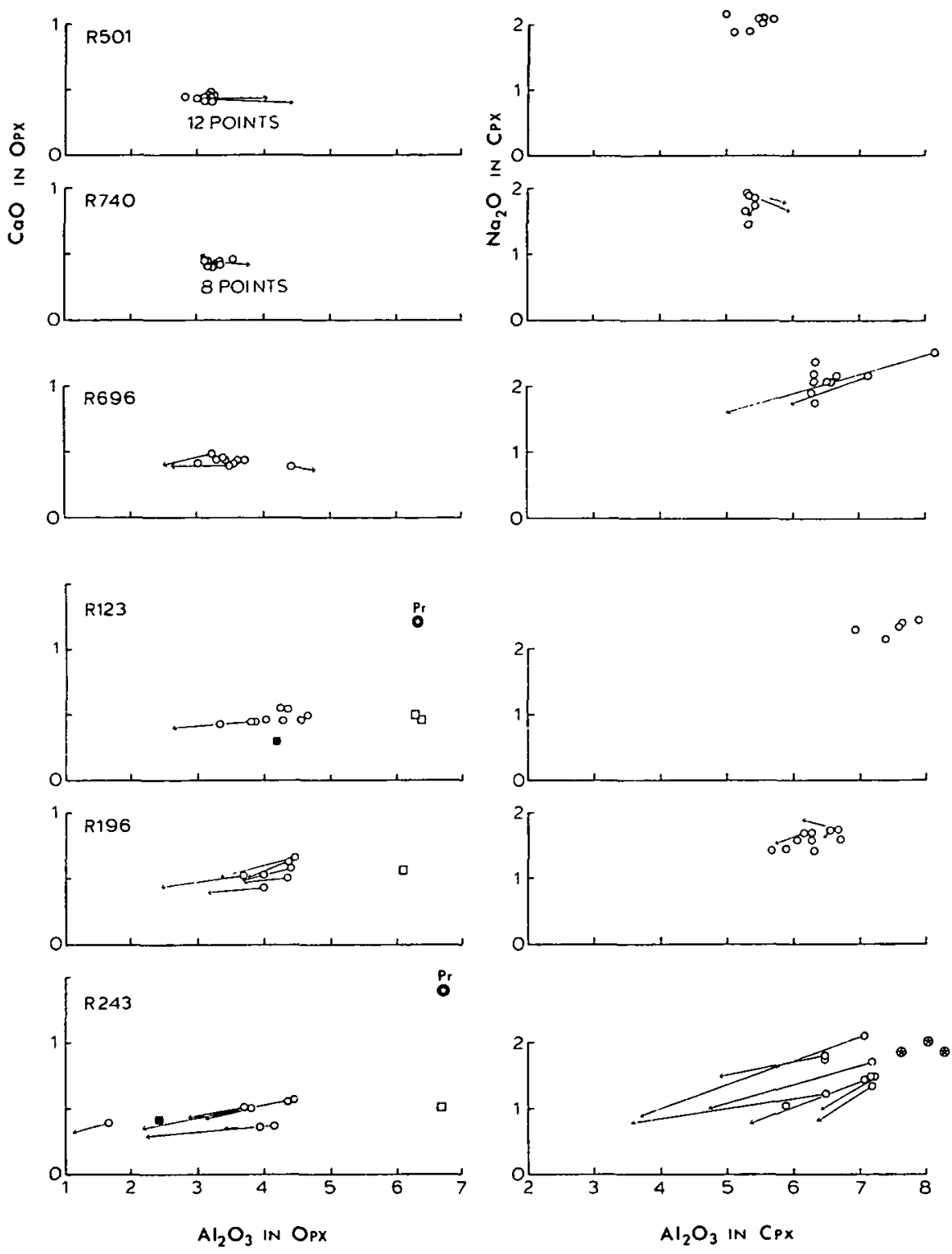

FIG. 9. $\mathrm{Al}_{2} \mathrm{O}_{3}-\mathrm{CaO}$ wt. per cent variations in orthopyroxene (left) and $\mathrm{Al}_{2} \mathrm{O}_{3}-\mathrm{Na}_{2} \mathrm{O}$ wt. per cent variations in clinopyroxene (right) from 12 peridotites. Diagrams are arranged in a geographic order of the samples from northwest (top) to southeast (bottom). Symbols: open circles = core of neoblasts, zoning is indicated by arrows; open squares $=$ host core of porphyroclasts; stars = exsolution lamellae in the porphyroclasts; solid

grain margins where they become more aluminous. The core compositions are assumed to be the equilibrium ones in the garnet peridotites. 'Tiny spinels' are considerably more aluminous than the medium-grained ones and appear to be younger because of their extremely small grain size $(\sim 20 \mu)$ and the presence of sulfide veins. Furthermore, their large $\mathrm{Al} / \mathrm{Cr}$ ratios suggest that the 'tiny spinels' are not in equilibrium with the garnets. 

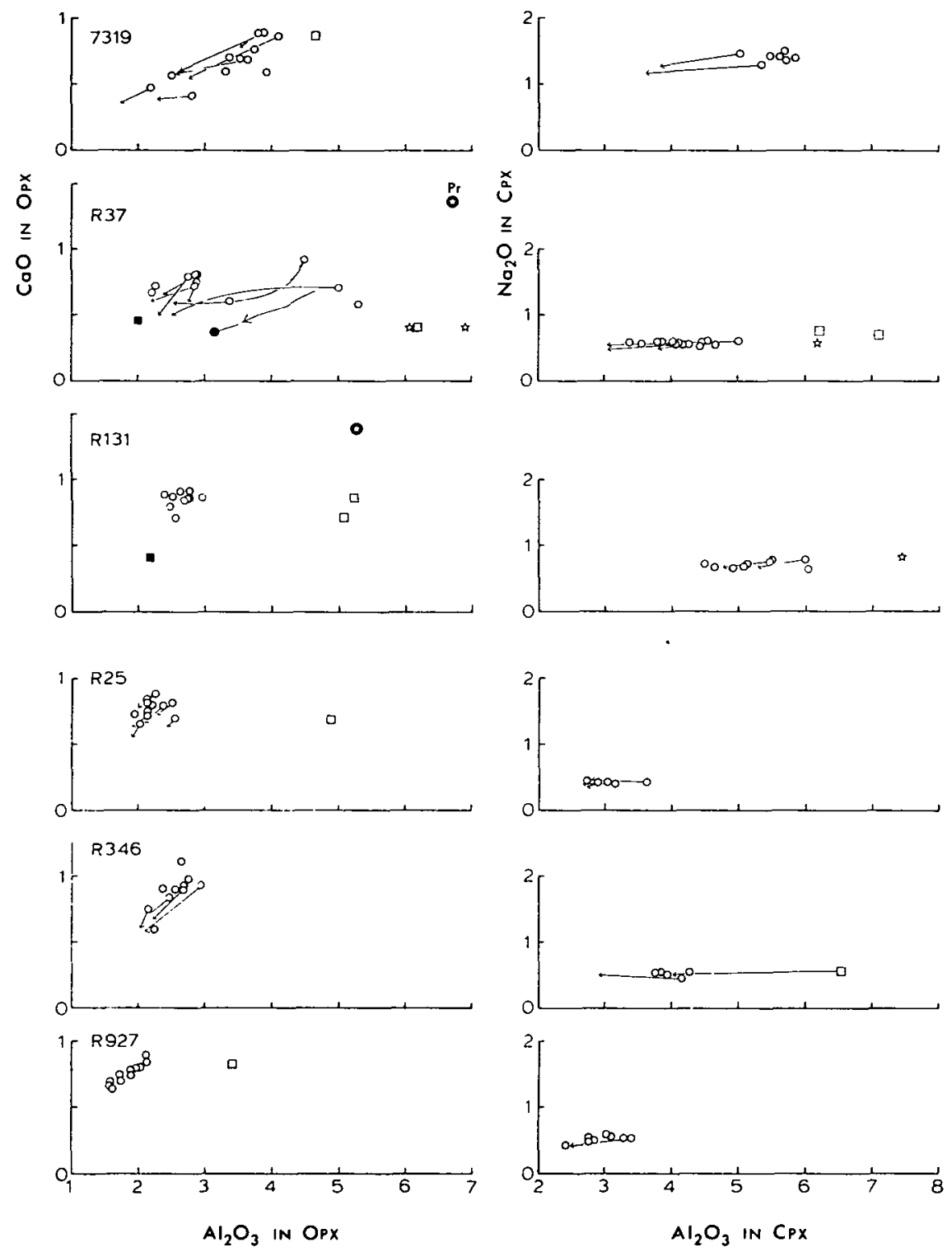

circles with white stars = averages of cores of porphyroclasts obtained by defocused electron-beam microprobe analyses; 'Pr' = 'primary compositions'; solid squares = rim of porphyroclasts; open circles with solid stars = core of 'turbid' clinopyroxene grains (from sample R243) obtained by defocused electron-beam microprobe analyses.

\section{Garnet}

Compared with pyroxene and spinel, garnet is rather homogeneous except for $\mathrm{Cr}_{2} \mathrm{O}_{3}$. For example, $\mathrm{Fe} / \mathrm{Mg}$ tends to increase only slightly at grain margins, but $\mathrm{Cr}_{2} \mathrm{O}_{3}$ varies erratically, by as much as one fifth. No systematic correlation between chemical composition and grain size has been found. Average garnet analyses are listed in Table 5 . They contain up to 70 mole per cent pyrope similar 
T A B LE 4

Average analyses of spinels from peridotites

\begin{tabular}{|c|c|c|c|c|c|c|c|c|c|c|c|c|c|c|c|c|c|}
\hline & \multicolumn{2}{|c|}{$R 501$} & \multicolumn{2}{|c|}{$R 740$} & \multicolumn{2}{|c|}{$R 696$} & \multirow[t]{2}{*}{$R 123$} & \multirow[t]{2}{*}{$R 196$} & \multirow[t]{2}{*}{$R 243$} & \multirow[t]{2}{*}{7319} & \multicolumn{2}{|c|}{$R 37$} & \multicolumn{2}{|c|}{$R I 31$} & \multirow[t]{2}{*}{$R 25$} & \multirow[t]{2}{*}{$R 346$} & \multirow[t]{2}{*}{$R 927$} \\
\hline & $m$ & $t$ & $m$ & $t$ & $m$ & $t$ & & & & & $l$ & $s$ & $l$ & $s$ & & & \\
\hline $\begin{array}{l}\mathrm{TiO}_{2} \\
\mathrm{Al}_{2} \mathrm{O}_{3} \\
\mathrm{Cr}_{2} \mathrm{O}_{3} \\
\mathrm{FeO}^{*} \\
\mathrm{MnO} \\
\mathrm{MgO}\end{array}$ & $\begin{array}{c}0.06 \\
45 \cdot 3 \\
24 \cdot 2 \\
13 \cdot 1 \\
0.26 \\
17.7\end{array}$ & $\begin{array}{c}- \\
55.7 \\
13 \cdot 1 \\
11 \cdot 3 \\
0.11 \\
19.8\end{array}$ & $\begin{array}{c}0.05 \\
50.2 \\
18.4 \\
11.8 \\
0.20 \\
19.3\end{array}$ & $\begin{array}{c}0.02 \\
51.7 \\
17.5 \\
11.7 \\
- \\
19.6\end{array}$ & $\begin{array}{c}0.04 \\
54.5 \\
14.1 \\
12.0 \\
0.22 \\
19.4\end{array}$ & $\begin{array}{c}- \\
60.0 \\
8.3 \\
11.1 \\
0.17 \\
20.5\end{array}$ & $\begin{array}{c}0.06 \\
58.4 \\
9.8 \\
12.1 \\
0.15 \\
19.6\end{array}$ & $\begin{array}{c}0.05 \\
55.7 \\
11.8 \\
11.0 \\
0.20 \\
20.8\end{array}$ & $\begin{array}{c}0.09 \\
58.7 \\
9.7 \\
11.0 \\
0.13 \\
20.3\end{array}$ & $\begin{array}{c}0.09 \\
43 \cdot 1 \\
25 \cdot 3 \\
13 \cdot 1 \\
0 \cdot 35 \\
18 \cdot 3\end{array}$ & $\begin{array}{c}0.06 \\
54.4 \\
13.9 \\
11.1 \\
0.19 \\
20.4\end{array}$ & $\begin{array}{c}0.15 \\
39.9 \\
28.7 \\
14.4 \\
0.42 \\
16.4\end{array}$ & $\begin{array}{c}0.36 \\
43.2 \\
21.8 \\
14 \cdot 3 \\
0.32 \\
19.6\end{array}$ & $\begin{array}{c}0.59 \\
36.4 \\
29.1 \\
17 \cdot 3 \\
0.46 \\
16.6\end{array}$ & $\begin{array}{c}0.27 \\
32.0 \\
35 \cdot 1 \\
17.1 \\
0.62 \\
15.9\end{array}$ & $\begin{array}{c}0.38 \\
34.0 \\
33.2 \\
16.1 \\
0.52 \\
16.5\end{array}$ & $\begin{array}{c}0.33 \\
31.5 \\
35.4 \\
17.5 \\
0.53 \\
14.9\end{array}$ \\
\hline TOTAL & $100 \cdot 6$ & $100 \cdot 0$ & $100 \cdot 0$ & $100 \cdot 4$ & $100 \cdot 2$ & $100 \cdot 1$ & $100 \cdot 2$ & 99.6 & 99.9 & $100 \cdot 1$ & $100 \cdot 1$ & 99.9 & 99.6 & $100 \cdot 5$ & $100 \cdot 9$ & 100.6 & $100 \cdot 1$ \\
\hline \multicolumn{18}{|c|}{ Cations per 32 oxygens } \\
\hline $\begin{array}{l}\mathrm{Al} \\
\mathrm{Cr} \\
\mathrm{Fe}^{3+} \\
\mathrm{Ti}\end{array}$ & $\begin{array}{r}11.63 \\
4.17 \\
0.19 \\
0.01\end{array}$ & $\begin{array}{r}13.69 \\
2.16 \\
0.15 \\
-\end{array}$ & $\begin{array}{r}12.62 \\
3.10 \\
0.28 \\
0.01\end{array}$ & $\begin{array}{c}12.86 \\
2.91 \\
0.23 \\
-\end{array}$ & $\begin{array}{r}13.47 \\
2.33 \\
0.19 \\
0.01\end{array}$ & $\begin{array}{r}14.48 \\
1.35 \\
0.17 \\
-\end{array}$ & $\begin{array}{r}14.23 \\
1.60 \\
0.15 \\
0.01\end{array}$ & $\begin{array}{r}13.65 \\
1.94 \\
0.40 \\
0.01\end{array}$ & $\begin{array}{r}14.26 \\
1.57 \\
0.15 \\
0.01\end{array}$ & $\begin{array}{r}11 \cdot 15 \\
4.39 \\
0.44 \\
0.02\end{array}$ & $\begin{array}{r}13.38 \\
2.29 \\
0.33 \\
0.01\end{array}$ & $\begin{array}{r}10.58 \\
5.10 \\
0.29 \\
0.03\end{array}$ & $\begin{array}{r}11.10 \\
3.77 \\
1.06 \\
0.06\end{array}$ & $\begin{array}{l}9.71 \\
5.19 \\
0.98 \\
0.10\end{array}$ & $\begin{array}{l}8.69 \\
6.38 \\
0.87 \\
0.05\end{array}$ & $\begin{array}{l}9.14 \\
5.99 \\
0.79 \\
0.07\end{array}$ & $\begin{array}{l}8.69 \\
6.54 \\
0.71 \\
0.06\end{array}$ \\
\hline Sum Al to Ti & 16.00 & $16 \cdot 00$ & 16.00 & 16.00 & 16.00 & $16 \cdot 00$ & 16.00 & $16 \cdot 00$ & $16 \cdot 00$ & $16 \cdot 00$ & 16.00 & 15.99 & 15.99 & 15.98 & 15.99 & 15.98 & $15 \cdot 99$ \\
\hline $\begin{array}{l}\mathrm{Fe}^{2+} \\
\mathrm{Mg} \\
\mathrm{Mn}\end{array}$ & $\begin{array}{l}2.20 \\
5.76 \\
0.05\end{array}$ & $\begin{array}{l}1.83 \\
6 \cdot 16 \\
0.02\end{array}$ & $\begin{array}{l}1.83 \\
6.14 \\
0.04\end{array}$ & $\begin{array}{c}1.84 \\
6.16 \\
-\end{array}$ & $\begin{array}{l}1.92 \\
6.05 \\
0.04\end{array}$ & $\begin{array}{l}1.73 \\
6.25 \\
0.03\end{array}$ & $\begin{array}{l}1.94 \\
6.03 \\
0.03\end{array}$ & $\begin{array}{l}1.51 \\
6.45 \\
0.04\end{array}$ & $\begin{array}{l}1.75 \\
6.23 \\
0.02\end{array}$ & $\begin{array}{l}1.96 \\
5.97 \\
0.07\end{array}$ & $\begin{array}{l}1.62 \\
6.35 \\
0.03\end{array}$ & $\begin{array}{l}2.41 \\
5.50 \\
0.08\end{array}$ & $\begin{array}{l}1.56 \\
6.38 \\
0.06\end{array}$ & $\begin{array}{l}2.30 \\
5.60 \\
0.09\end{array}$ & $\begin{array}{l}2.43 \\
5.45 \\
0.12\end{array}$ & $\begin{array}{l}2.29 \\
5.61 \\
0.10\end{array}$ & $\begin{array}{l}2.72 \\
5.17 \\
0.11\end{array}$ \\
\hline Sum ${ }^{+2}$ ions & 8.00 & 8.00 & 8.00 & 8.00 & 8.00 & 8.00 & 8.00 & 8.00 & 8.00 & $8 \cdot 00$ & 8.00 & 8.00 & 7.99 & 7.99 & 7.99 & 7.99 & 7.99 \\
\hline
\end{tabular}


TABLE 5

Analyses of garnets from peridotites

\begin{tabular}{|c|c|c|c|c|}
\hline Rock no. & $R 501$ & $R 740$ & $R 696$ & $R 123$ \\
\hline $\mathrm{SiO}_{2}$ & $42 \cdot 37$ & 42.42 & $42 \cdot 64$ & $41 \cdot 79$ \\
\hline $\mathrm{TiO}_{2}$ & 0.17 & 0.17 & 0.15 & 0.30 \\
\hline $\mathrm{Al}_{2} \mathrm{O}_{3}$ & $22 \cdot 46$ & $22 \cdot 58$ & $22 \cdot 83$ & 22.90 \\
\hline $\mathrm{Cr}_{2} \mathrm{O}_{3}$ & $1 \cdot 38$ & $1 \cdot 10$ & 0.71 & 0.53 \\
\hline $\mathrm{FeO}^{*}$ & $8 \cdot 50$ & 8.01 & 9.23 & 9.22 \\
\hline $\mathrm{MnO}$ & 0.41 & 0.35 & 0.37 & 0.32 \\
\hline $\mathrm{MgO}$ & $20 \cdot 56$ & $20 \cdot 27$ & 20.06 & 19.82 \\
\hline $\mathrm{CaO}$ & $5 \cdot 04$ & 5.01 & $4 \cdot 74$ & 4.65 \\
\hline \multirow[t]{2}{*}{ TOTAL } & 100.89 & 99.91 & $100 \cdot 73$ & 99.53 \\
\hline & \multicolumn{3}{|c|}{ Cations per 12 oxygens } & \\
\hline $\mathrm{Si}$ & 2.994 & 3.014 & 3.015 & 2.991 \\
\hline $\mathrm{Ti}$ & 0.009 & 0.009 & 0.008 & 0.016 \\
\hline Al & 1.870 & 1.891 & 1.902 & 1.932 \\
\hline $\mathrm{Cr}$ & 0.077 & 0.062 & 0.040 & 0.030 \\
\hline $\mathrm{Fe}$ & 0.502 & 0.476 & 0.546 & 0.552 \\
\hline $\mathrm{Mn}$ & 0.025 & 0.021 & 0.022 & 0.019 \\
\hline $\mathrm{Mg}$ & $2 \cdot 165$ & $2 \cdot 147$ & $2 \cdot 114$ & $2 \cdot 115$ \\
\hline $\mathrm{Ca}$ & 0.382 & 0.381 & 0.359 & 0.357 \\
\hline TOTAL & 8.024 & 8.001 & 8.006 & 8.012 \\
\hline
\end{tabular}

- Total Fe as FeO.

to garnets from peridotite nodules in kimberlite and from other alpine-type garnet peridotites. $\mathrm{CaO}$ varies from 4.6 to 5.1 wt. per cent, and $\mathrm{Cr}_{2} \mathrm{O}_{3}$ varies from 0.5 to 1.4 wt. per cent. These two elements vary sympathetically among the four peridotites, suggesting some coupling of $\mathrm{Ca}$ and $\mathrm{Cr}$ atoms in the garnet structure.

\section{Amphibole}

Chemical analyses of the secondary amphiboles from four garnet peridotites and two spinel peridotites are listed in Table 6. They are pargasitic hornblende with rather high $\mathrm{Ti}$ and $\mathrm{Cr}$ contents; $\mathrm{K}$ is less than the detection limit of microprobe (i.e. $<0.01$ wt. per cent).

\section{Olivine}

The forsterite content, per cent $\mathrm{Mg} /(\mathrm{Mg}+\mathrm{Fe})$, of olivines from the 12 peridotites is included in Table 1. It ranges from 91.7 to 87.8 with a maximum frequency around 90. Individual olivine grains are homogeneous within the analytical precision although a slight variation was seen among grains. On the average, however, there is no difference in $\mathrm{Mg} /(\mathrm{Mg}+\mathrm{Fe})$ between large and small grains as is also true for orthopyroxene. Obviously, the $\mathrm{Mg} /(\mathrm{Mg}+\mathrm{Fe})$ ratio of olivine and orthopyroxene did not change appreciably during recrystallization, consistent with the experimental results of Matsui \& Nishizawa (1974) who showed that $\mathrm{Fe}-\mathrm{Mg}$ partitioning between olivine and orthopyroxene from peridotite is insensitive to temperature and pressure. 
TAB LE 6

Selected analyses of amphiboles from peridotites

\begin{tabular}{|c|c|c|c|c|c|c|}
\hline & R50I & $R 740$ & $R 696$ & $R 123$ & $R 243$ & 7319 \\
\hline $\mathrm{SiO}_{2}$ & 43.65 & 43.58 & 43.65 & 43.34 & 44.27 & 42.58 \\
\hline $\mathrm{TiO}_{2}$ & 1.96 & 2.35 & 2.72 & 2.95 & 2.87 & 1.87 \\
\hline $\mathrm{Al}_{2} \mathrm{O}_{3}$ & 15.15 & 14.62 & 13.81 & 15.08 & 14.03 & 14.11 \\
\hline $\mathrm{Cr}_{2} \mathrm{O}_{3}$ & 1.20 & 1.05 & 1.03 & 0.84 & 0.97 & 1.86 \\
\hline $\mathrm{FeO}^{*}$ & 3.45 & 3.40 & 4.16 & 4.24 & 3.70 & $3 \cdot 12$ \\
\hline $\mathrm{MnO}$ & 0.05 & 0.07 & 0.06 & 0.07 & 0.09 & 0.07 \\
\hline $\mathrm{MgO}$ & 17.68 & $18 \cdot 20$ & 17.70 & 16.99 & 17.35 & 18.55 \\
\hline $\mathrm{CaO}$ & 11.28 & 11.49 & $11 \cdot 12$ & $11 \cdot 19$ & 11.99 & 11.96 \\
\hline $\mathrm{Na}_{2} \mathrm{O}$ & 3.68 & 3.47 & 3.25 & 4.06 & $3 \cdot 20$ & 3.64 \\
\hline $\mathrm{K}_{2} \mathrm{O}$ & 0.00 & n.d. & n.d. & n.d. & n.d. & n.d. \\
\hline TOTAL & $98 \cdot 10$ & $98 \cdot 23$ & 97.50 & 98.76 & 98.47 & 97.76 \\
\hline \multicolumn{7}{|c|}{ Cations per 23 oxygens } \\
\hline $\mathrm{Si}$ & $6 \cdot 145$ & $6 \cdot 131$ & $6 \cdot 197$ & 6.092 & $6 \cdot 216$ & 6.053 \\
\hline $\mathrm{Ti}$ & 0.207 & 0.249 & 0.290 & 0.312 & 0.303 & 0.200 \\
\hline Al & 2.514 & 2.425 & 2.311 & 2.499 & $2 \cdot 323$ & 2.365 \\
\hline $\mathrm{Cr}$ & 0.134 & 0.117 & 0.116 & 0.093 & 0.108 & 0.209 \\
\hline $\mathrm{Fe}$ & 0.406 & 0.400 & 0.494 & 0.498 & 0.435 & 0.371 \\
\hline $\mathrm{Mn}$ & 0.006 & 0.008 & 0.007 & 0.008 & 0.011 & 0.008 \\
\hline $\mathrm{Mg}$ & 3.710 & 3.816 & 3.745 & 3.559 & 3.631 & 3.930 \\
\hline $\mathrm{Ca}$ & 1.701 & 1.732 & 1.692 & 1.685 & 1.804 & 1.822 \\
\hline $\mathrm{Na}$ & 1.004 & 0.947 & 0.895 & 1.107 & 0.871 & 1.003 \\
\hline $\mathrm{k}$ & 0.000 & n.d. & n.d. & n.d. & n.d. & n.d. \\
\hline TOTAL & 15.827 & 15.823 & 15.747 & 15.854 & 15.701 & 15.962 \\
\hline
\end{tabular}

* Total Fe as FeO.

\section{ELEMENT PARTITIONING AND EQUILIBRIUM CONDITIONS}

At least two stages of crystallization are distinguished. Late stage, recrystallization conditions may be obtained from the pyroxene neoblast compositions, whereas earlier $P-T$ conditions may be obtained from the pyroxene porphyroclast compositions.

\section{Recrystallization conditions}

\section{Diopside-enstatite geothermometer}

$\mathrm{The} \mathrm{Ca} /(\mathrm{Ca}+\mathrm{Mg})$ ratios of the clinopyroxene neoblasts from the investigated Ronda peridotites are listed in Table 7. Application of the Boyd geothermometer (Boyd, 1973) results in temperature estimates near $1000^{\circ} \mathrm{C}$ or less. The Ronda pyroxenes are, however, distinctly more aluminous ( 3 to 8 wt. per cent $\mathrm{Al}_{2} \mathrm{O}_{3}$ ) than those from kimberlite nodules (typically below 1.5, Boyd 1973), and so without knowing the effect of $\mathrm{Al}$ on the diopside-enstatite solvus, the errors involved in this method are difficult to estimate.

Listed also in Table 7 are temperature estimates obtained with the method of Wells (1977), an updated version of the semi-empirical, thermodynamic approach of Wood \& Banno (1973). The estimated temperatures range from 876 to $1048{ }^{\circ} \mathrm{C}$ 
T A B LE 7

Element partitioning data and temperature estimates for peridotites

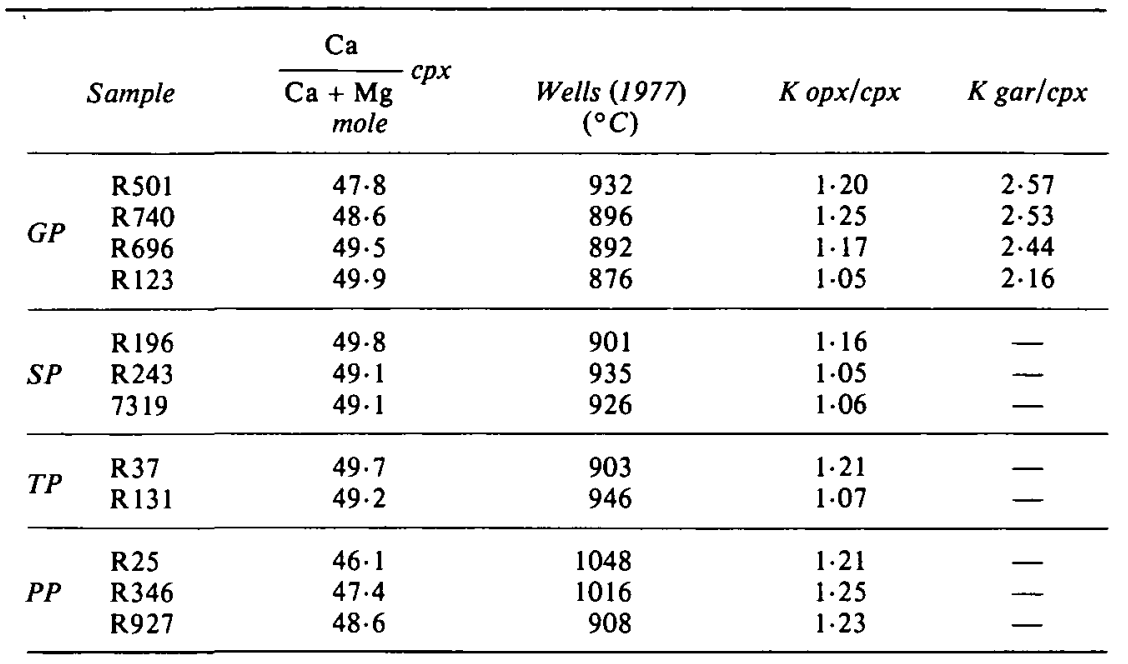

$G P=$ garnet peridotite; $S P=$ spinel peridotite; $T P=$ transitional peridotite; $P P=$ plagioclase peridotite.

with a mean value of $930^{\circ} \mathrm{C}$. Lower-pressure samples (plagioclase peridotites) record, on the average, slightly higher temperatures than higher-pressure samples (garnet peridotites). This apparent temperature increase from the higher- to lower-pressure samples may be a pressure effect upon the pyroxene solvus (Mori \& Green, 1975; Nehru \& Wyllie, 1974), which is not taken into account in the Wells' geothermometer. This pressure effect may also account for the observed monotonical increase in the $\mathrm{CaO}$ content in orthopyroxene neoblasts from higherto lower-pressure samples (see Fig. 8).

Wells' method (or that of Wood \& Banno) assumes a linear relationship between logarithm $K$ and reciprocal $T$ (by analogy to the ideal solution case); however, this approximation may break down at lower temperatures (note fig. 1 of Wells, 1977 that experimental data are poorly fit by a straight line below $900^{\circ} \mathrm{C}$ ), probably because the non-ideality of the pyroxene solid solution increases as temperature decreases. If the $\ln K-1 / T$ relationship is represented by a curve instead of a straight line as Mori (1977) suggested, the temperature estimates above should be somewhat overestimated.

\section{Fe-Mg partitioning}

The partition coefficients

$$
K \mathrm{opx} / \mathrm{cpx}=\frac{(\text { total } \mathrm{Fe} / \mathrm{Mg}) \text { opx }}{(\text { total } \mathrm{Fe} / \mathrm{Mg}) \mathrm{cpx}}
$$

and

$$
K \mathrm{gar} / \mathrm{cpx}=\frac{(\text { total } \mathrm{Fe} / \mathrm{Mg}) \mathrm{gar}}{(\text { total } \mathrm{Fe} / \mathrm{Mg}) \mathrm{cpx}}
$$


are listed in Tables 7 and 8 for peridotites and mafic layers, respectively. $K$ opx/cpx values are rather constant, 1.05 to 1.31 for both peridotites and mafic layers, whereas $K$ gar/cpx values are 2.16 to 2.57 for peridotites and 1.32 to 3.32 for garnet pyroxenites. The greater spread in $K$ gar/cpx values than in $K$ opx/cpx values may be due to the fact that the former is more sensitive to physical conditions (e.g. Banno, 1970) and to mineral composition (Oka \& Mastumoto, 1974; Ganguly, 1978; see wide ranges of chemical variations in clinopyroxenes and garnets, Table 8) than the latter.

Laboratory calibrations have been made on the $K$ gar/cpx values for tholeiitic compositions (Rảheim \& Green, 1974) and on the $K$ opx/cpx and $K \mathrm{gar} / \mathrm{cpx}$ values for peridotite compositions (Mori \& Green, 1978), but their direct applications to natural rocks cannot be safely made until $\mathrm{Fe}^{3+} / \mathrm{Fe}^{2+}$ ratios are determined in natural minerals because these ratios are presumably different in much reduced synthetic conditions than in natural environments. For example, temperatures of $950^{\circ} \mathrm{C}$ and $1070^{\circ} \mathrm{C}$ may be obtained for the mean values of $K$ opx/cpx and $K$ gar/cpx of the peridotites, respectively, using Mori \& Green's temperature calibrations, but if only $\mathrm{Fe}^{2+}$ were used instead of total $\mathrm{Fe}$, somewhat greater $K$ values and hence lower temperatures would be obtained (Lappin \& Smith, 1978).

\section{Spinel-olivine geothermometer}

$K$ spinel/olivine values, defined as

$$
\frac{\left(\mathrm{Fe}^{2+} / \mathrm{Mg}\right) \text { spinel }}{\left(\mathrm{Fe}^{2+} / \mathrm{Mg}\right) \text { olivine }}
$$

have been calculated by pairing all the spinel analyses with the average compositions of olivines for each peridotite and are plotted in the $\ln K$ vs $Y_{\mathrm{Cr}}$

T A B LE 8

Element partitioning data for mafic layers

\begin{tabular}{|c|c|c|c|c|c|c|c|}
\hline \multirow[t]{2}{*}{ Sample } & \multirow[t]{2}{*}{ Mineral assemblage } & \multirow[t]{2}{*}{$K o p x / c p x$} & \multirow[t]{2}{*}{$K$ gar/cpx } & \multicolumn{3}{|c|}{ Clinopyroxene } & \multirow{2}{*}{$\begin{array}{c}\text { Garnet } \\
\mathrm{CaO} \\
w t\end{array}$} \\
\hline & & & & $\underset{\text { mole }}{M g / M g}+F e$ & $\begin{array}{c}\mathrm{Al}_{2} \mathrm{O}_{3} \\
w t\end{array}$ & $\begin{array}{c}\mathrm{Na}_{2} \mathrm{O} \\
w t\end{array}$ & \\
\hline R 127 & $\mathrm{Gar}+\mathrm{Cpx}+\mathrm{Plag}$ & - & $2 \cdot 38$ & 76 & $8 \cdot 2$ & 1.0 & $7 \cdot 4$ \\
\hline R253 & Gar + Cpx + Plag & - & 3.02 & 76 & $8 \cdot 0$ & $1 \cdot 3$ & 5.6 \\
\hline R560 & Gar + Cpx + Plag & - & 2.54 & 91 & $10 \cdot 5$ & 1.4 & $6 \cdot 5$ \\
\hline R525 & $\mathrm{Gar}+\mathrm{Cpx}$ & - & $3 \cdot 36$ & 75 & $5 \cdot 2$ & $2 \cdot 0$ & 6.4 \\
\hline R410 & $\mathrm{Gar}+\mathrm{Cpx}+$ Plag $+\mathrm{Qz}$ & - & $3 \cdot 17$ & 90 & $11 \cdot 3$ & 1.9 & 9.2 \\
\hline R554 & $G a r+C p x+O p x$ & $1 \cdot 20$ & 2.91 & 85 & $7 \cdot 0$ & 2.9 & 4.2 \\
\hline 387 & $\mathrm{Gar}+\mathrm{Cpx}+\mathrm{Opx}+\mathrm{Ol}$ & $1 \cdot 13^{*}$ & $1 \cdot 32^{*}$ & 90 & $7 \cdot 7$ & $2 \cdot 2$ & 4.5 \\
\hline R251 & $\mathrm{Cpx}+\mathrm{Opx}+\mathrm{Plag}+\mathrm{Sp}$ & $1 \cdot 31$ & - & 84 & $5 \cdot 5$ & 0.7 & - \\
\hline R 120 & $\mathrm{Cpx}+\mathrm{Opx}+\mathrm{Plag}+\mathrm{Ol}+\mathrm{Sp}$ & $1 \cdot 22$ & - & 89 & $3 \cdot 9$ & 0.6 & - \\
\hline R343 & $\mathrm{Cpx}+\mathrm{Opx}+\mathrm{Plag}+\mathrm{Ol}+\mathrm{Sp}$ & 1.24 & - & 87 & $3 \cdot 0$ & 0.4 & - \\
\hline 339 & $\mathrm{Cpx}+\mathrm{Opx}+\mathrm{Plag}+\mathrm{Ol}+\mathrm{Sp}$ & $1 \cdot 19$ & - & 89 & $3 \cdot 3$ & 0.7 & - \\
\hline 410 & $\mathrm{Cpx}+\mathrm{Opx}+\mathrm{Plag}+\mathrm{Ol}+\mathrm{Sp}$ & 1.06 & - & 86 & 4.8 & 0.5 & - \\
\hline
\end{tabular}

387, 339 and 410, Schubert 1977; all others, unpublished data, Obata 1977; sample locations in Fig. 3.

R127, R251, R120 and R343 are new analyses of samples in Dickey 1970.

* Pyroxenes are strongly zoned; high-Al core compositions used. 
diagram in Fig. $10.700{ }^{\circ} \mathrm{C}$ and $1200^{\circ} \mathrm{C}$ isopleths are from Evans \& Frost (1975), and the intervening isopleths are in proportion to $1 / T$. $\ln K$ was not normalized to $\mathrm{X}_{\mathrm{Fe}^{3+}}=0.05$ (the value suggested by Evans \& Frost) because the uncertainty of the correction factor derived from thermochemical data by Irvine (1965) is thought to be too large. However, the isotherms in Fig. 10 do not shift significantly even if un-normalized values are used because the $\mathrm{X}_{\mathrm{Fe}^{3+}}$ values used by Evans \& Frost average $0 \cdot 05$.

Interestingly, for the garnet peridotites there are no systematic temperature differences estimated from large and small spinel grains and the zoning is nearly isothermal; they all seem to have equilibrated between 800 and $900{ }^{\circ} \mathrm{C}$. However, in the transitional peridotites, the centers of large spinel grains indicate temperatures up to $1200^{\circ} \mathrm{C}$, and they are zoned outwards toward lower temperatures (see Fig. 10). Small grains in the same rocks give a temperature range of 800 to $900^{\circ} \mathrm{C}$. Temperature estimates for spinel peridotites range from 800 to $1100{ }^{\circ} \mathrm{C}$, and for plagioclase peridotites the range is 850 to $950^{\circ} \mathrm{C}$.

Although the Evans \& Frost (1975) calibration of the olivine-spinel geothermometer is based on natural mineral pairs and indirect temperature estimates, recent hydrothermal experimental data on the olivine-spinel equilibria (Engi, 1978) prove that their location of the $700^{\circ} \mathrm{C}$-isotherm is approximately correct in the compositional range of $Y_{\mathrm{Cr}}=0$ to $0 \cdot 5$. So the temperature estimates by this method have an experimental basis and are reliable, at least between 700 and $900{ }^{\circ} \mathrm{C}$.

\section{Al in pyroxenes}

$\mathrm{Al}_{2} \mathrm{O}_{3}$ solubility in orthopyroxene in spinel lherzolite assemblages is primarily a function of temperature and not so much of pressure, especially below $1000{ }^{\circ} \mathrm{C}$ (Wood, 1975; Obata, 1976; Fujii, 1976). Three peridotite samples, R123, R196 and R243, were chosen for application of the geothermometer because they contain the most aluminous spinels $(\mathrm{Al} / \mathrm{Al}+\mathrm{Cr}$ is 90,88 and 90 mole per cent, respectively) among the 12 peridotites investigated, and therefore, possible errors due to the erroneous correction for $\mathrm{Cr}$ in spinel are minimized. $\mathrm{The} \mathrm{Al}_{2} \mathrm{O}_{3}$ content in orthopyroxenes from these samples are 4.06, 4.19 and 4.04 wt. per cent, respectively. The temperature estimates for these samples, reading from fig. 2 in Obata (1976) are about $900^{\circ} \mathrm{C}$. If the new version of Danckwerth \& Newton (1978, fig. 7) is used instead, temperatures about $80^{\circ} \mathrm{C}$ less are obtained for the same samples. Including the ideal solution correction mainly for $\mathrm{Cr}$ and $\mathrm{Fe}$ in spinel (Stroh, 1976) would raise the temperature estimates some 80 to $100^{\circ} \mathrm{C}$; however this may be an overcorrection considering possible non-ideality in spinel solid solution (Dankwerth \& Newton, 1978). The above uncorrected temperature estimates agree well with the results of the two-pyroxene and spinel-olivine geothermometries within the range of uncertainties.

\section{A direct, experimental temperature estimate}

Obata \& Dickey (1976) experimentally crystallized plagioclase-garnet clinopyroxenite over a wide $P-T$ range starting from glass with the composition of a magmatic-type mafic layer R127, a sample from the garnet-lherzolite facies 

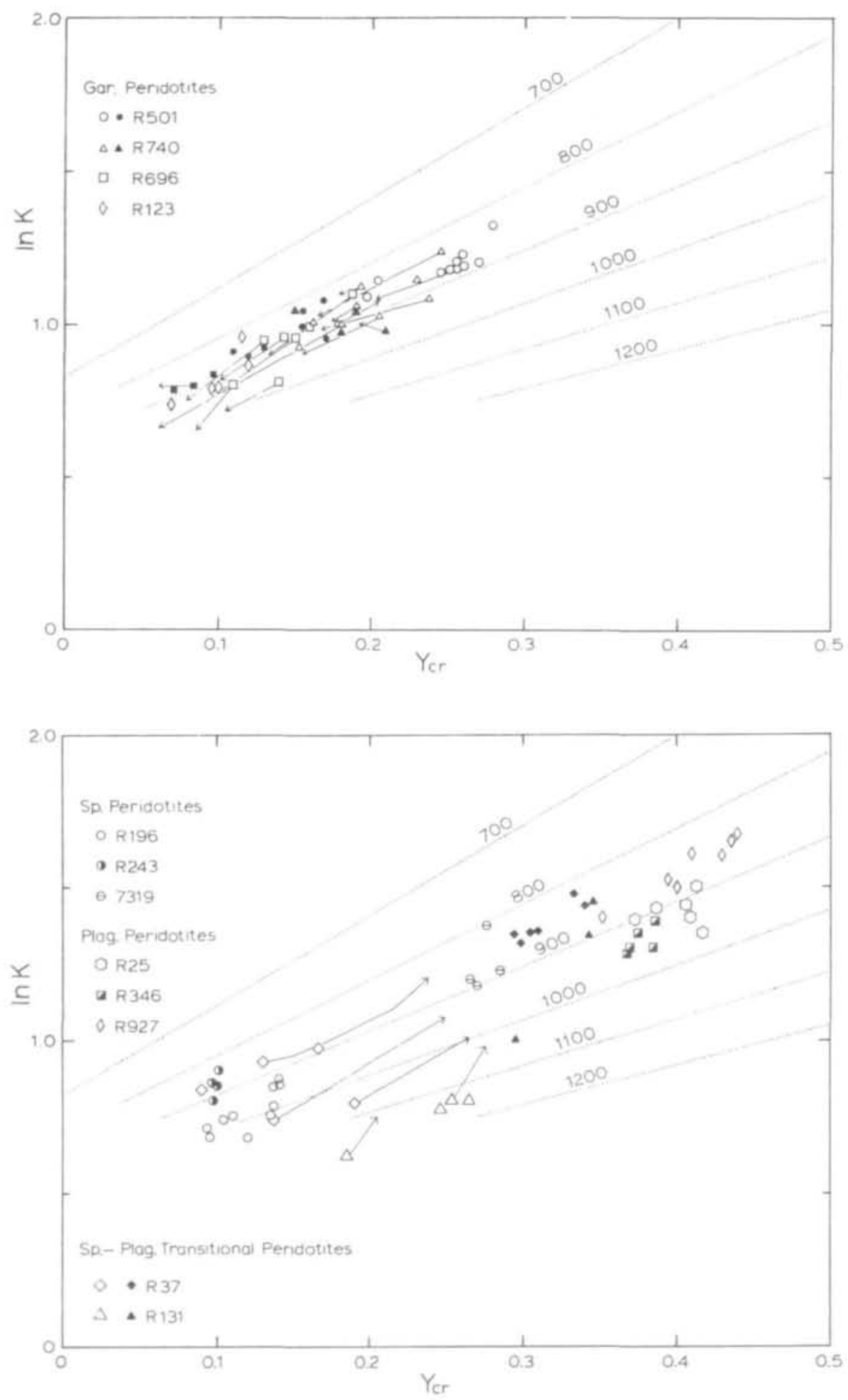

Fig. 10. In $K$ vs. $Y_{\mathrm{cr}}$ plot for spinel-olivine pairs from 4 garnet peridotites (top), and from other peridotites (bottom). $Y_{\mathrm{cr}}=\mathrm{Cr} /\left(\mathrm{Al}+\mathrm{Cr}+\mathrm{Fe}^{3+}\right)$ atoriic ratio of spinels. Direction of zoning is indicated by arrows. 
zone. By monitoring the compositions of the synthesized pyroxenes, they concluded that the natural rock had equilibrated between 800 and $900^{\circ} \mathrm{C}$. This temperature estimate agrees well with the spinel-olivine temperature estimates for the garnet peridotites.

\section{Pressure of recrystallization}

The average orthopyroxene composition of garnet peridotite R501 was used for pressure estimates because this is the most thoroughly equilibrated sample of garnet peridotite (see Figs. 8 and 9). Pressures of 12 to $15 \mathrm{~kb}$ were obtained at the equilibration temperatures of 800 to $900{ }^{\circ} \mathrm{C}$, by the method of Wood \& Banno (1973) and using the revised free energy value of Wood (1974) (Fig. 11).

The equilibration pressure of plagioclase peridotite samples was estimated to be 5 to $7 \mathrm{~kb}$ using the method of Obata (1976) for the same temperature range. This is near the plagioclase/spinel peridotite boundary (Fig. 11). The pressure difference between the formation of the garnet peridotite and the plagioclase peridotite is at least $5 \mathrm{~kb}$, too large to be accounted for by lithostatic pressure differences alone across the peridotite mass as noted before. If higher temperatures are used in the

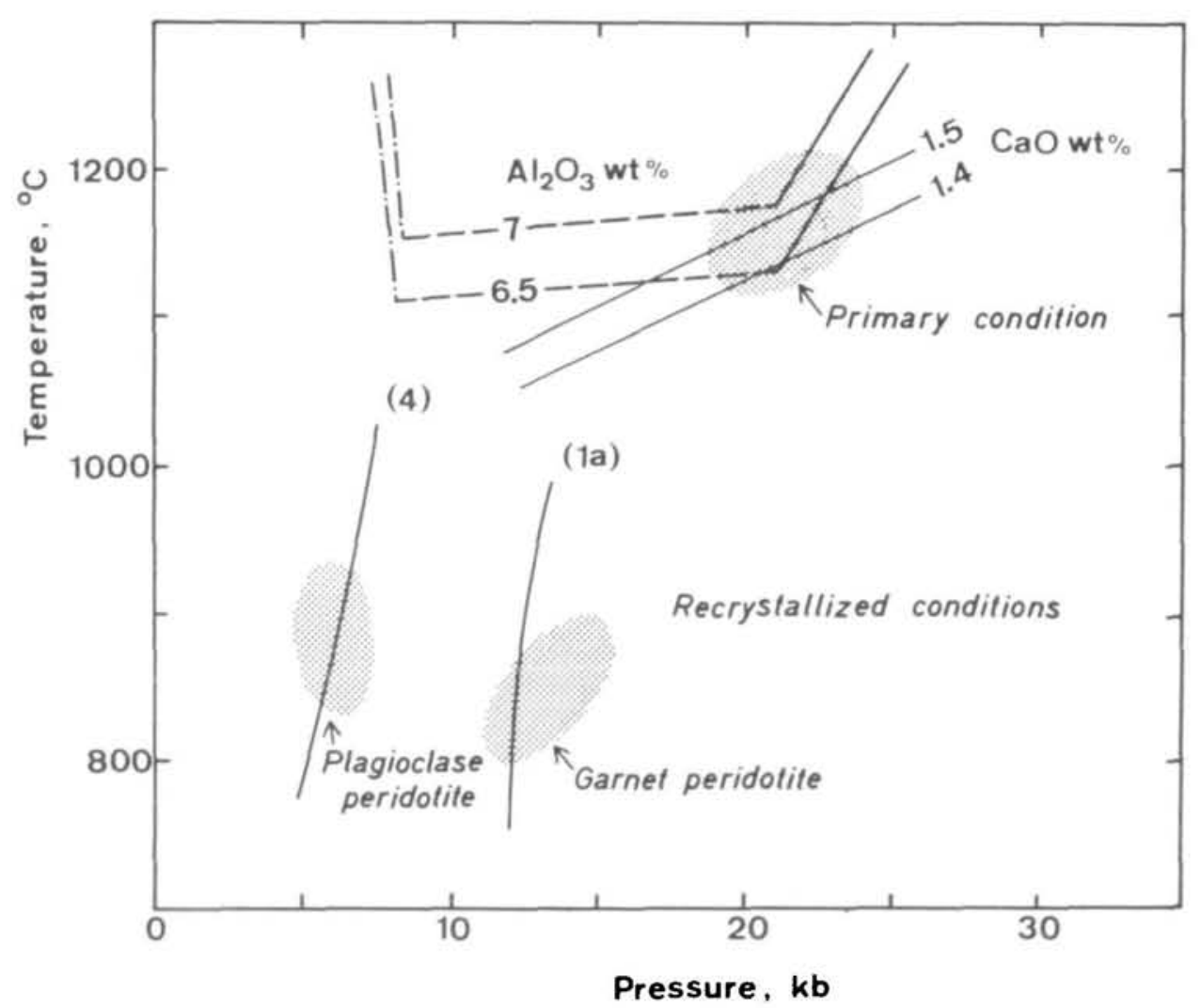

FIG. 11. Primary and recrystallized conditions of the Ronda peridotite. Isopleths are for $\mathrm{Al}_{2} \mathrm{O}_{3}$ wt. per cent in orthopyroxene in plagioclase peridotite (dash-dotted lines), in spinel peridotite (dashed lines), in garnet peridotite (thick solid lines), and for $\mathrm{CaO}$ wt. per cent in orthopyroxene coexisting with diopside (thin solid lines). Reaction curves (1a) and (4) are the same as in Fig. 5. 
calculations above, higher pressure values are obtained for the garnet peridotite, and lower pressure values for the plagioclase peridotite; the result is an even larger pressure gradient across the mass.

\section{Primary condition}

The pressure and temperature at which orthopyroxenes of the 'primary compositions' were formed is called the 'primary condition'. 'Primary' does not necessarily imply igneous; it is nothing more than the earliest stage that can be recognized by petrologic methods. In fact, it is an early metamorphic condition in the upper mantle as discussed later. The orthopyroxene 'primary composition' is 6 to 7 wt. per cent $\mathrm{Al}_{2} \mathrm{O}_{3}$ and 1.3 to 1.5 wt. per cent $\mathrm{CaO}$. In Fig. 11, isotherms are drawn for 6.5 and 7 wt. per cent $\mathrm{Al}_{2} \mathrm{O}_{3}$ in orthopyroxene in garnet peridotite (Akella, 1976) and in spinel and plagioclase peridotites in the system $\mathrm{CaO}-$ $\mathrm{MgO}-\mathrm{Al}_{2} \mathrm{O}_{3}-\mathrm{SiO}_{2}$ (Obata, 1976). If the rock is saturated with aluminous phases such as garnet, spinel or plagioclase, the primary condition must lie on the isopleths of these aluminous phases. If the rock is not saturated with the aluminous phases, the primary condition must lie somewhere above the isopleths.

Another $P-T$ constraint may be obtained from the $\mathrm{CaO}$ contents in the orthopyroxene. Isopleths for 1.4 to 1.5 wt. per cent $\mathrm{CaO}$ in orthopyroxene are added in Fig. 11, using accurate, reversed, experimental data in the diopsideenstatite system (Mori \& Green, 1975; Lindsley \& Dixon, 1976). The CaO isopleths happen to pass near the intersection of the $\mathrm{Al}_{2} \mathrm{O}_{3}$ isopleths for spinel- and garnet-peridotites; thereby defining a narrow $P-T$ range of 1100 to $1200^{\circ} \mathrm{C}$ and 20 to $25 \mathrm{~kb}$ for the 'primary condition' (Fig. 11). This temperature range coincides with the maximum temperatures recorded in the cores of the large spinel grains in the transitional peridotites. Because the primary condition is located close to the intersection of the $\mathrm{Al}_{2} \mathrm{O}_{3}$ isopleths for spinel and garnet peridotites, the peridotite was saturated, or nearly so, with spinel and garnet at the stage of the "primary condition'.

'Primary' does not necessarily imply igneous; it is nothing more than the earliest stage that can be recognized by petrologic methods. In fact, it is an early metamorphic condition in the upper mantle as discussed later.

Of course, much uncertainty is involved in this $P-T$ estimate due to inaccuracies of the phase diagrams and, especially, the unknown effect of $\mathrm{Al}_{2} \mathrm{O}_{3}$ on the enstatite solvus. It is clear, however, that the 'primary condition' was at much higher temperatures and pressures than the 'recrystallized conditions'.

\section{PRESSURE-TEMPERATURE TRAJECTORIES}

With the primary and recrystallized conditions estimated, the next question is how the latter were achieved from the former in the actual crystallization history of the Ronda peridotite. Theoretically, numbers of different ways in connecting these stages in pressure-temperature space may be considered, and petrological arguments alone are not adequate to reduce the degree of freedom because there are no accurate $P-T$ indicators for intermediate stages. It is also not obvious whether one kind of $P-T$ path is adequate for the entire body of peridotite, or 
whether different $P-T$ paths have to be considered for different parts of the body. Considerations on geophysical factors such as heat conduction may offer some constraints on the equilibration history of the peridotite.

Consider a hot peridotite mass that starts to ascend from a depth at which pressure and temperature are those of the primary condition, say from $70 \mathrm{~km}$ depth (Fig. 12). The peridotite is solid but mobile and continues to flow by syntectonic recrystallization and plastic deformation under shear stress at high temperatures (e.g. Carter \& Ave'Lallemant, 1970; Ave'Lallemant \& Carter, 1970; Nicolas et al., 1971). The outer part of the body loses heat by thermal condition to the cooler surroundings faster than the inside does. There will be a lower temperature limit for the syntectonic recrystallization; so as the peridotite cools, the recrystallization eventually stops successively from the outer part of the body toward the inside. Because pressure drops as well as temperature in this event, the outer part will first be frozen in high-pressure mineralogies (i.e. garnet peridotite with garnet pyroxenite layers), while the inside will later be frozen in lower-pressure mineralogies (i.e. plagioclase peridotite with olivine gabbro layers) at a shallower level, resulting in a mineralogically-zoned structure. Because of the slow heat conduction the cooling deep inside the body is nearly adiabatic, so when the

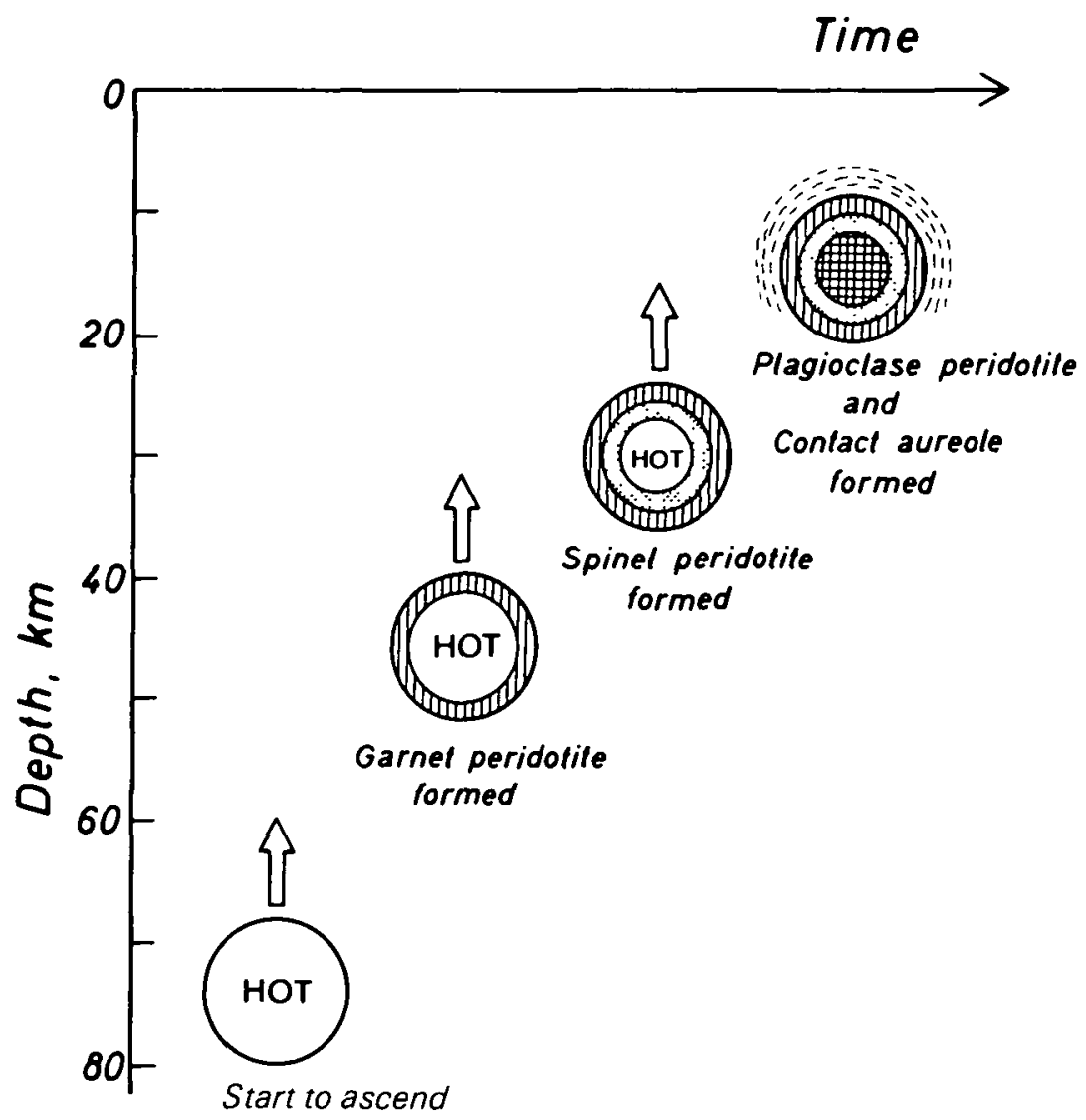

Fig. 12. Development of mineralogical zoning in a hot, ascending peridotite body. 
peridotite reaches the earth's crust, it is still hot inside and capable of metamorphosing the surrounding sediments (Casares Unit). By this stage, however, the outer-most part of the peridotite body would already have been frozen-in as garnet peridotite, and during the contact metamorphism of the sediments, only superficial, retrogressive reactions would affect this high-pressure zone (such as kelyphitization of garnet, symplectization of aluminous pyroxenes, exsolution and chemical zoning of pyroxenes, and perhaps formation of the 'tiny' spinel grains in the garnet peridotites). This mechanism would explain the large apparent pressure gap between the garnet peridotite $(12$ to $15 \mathrm{~kb})$ and the garnet-cordierite gneiss at the peridotite contact (approx. $4 \mathrm{~kb}$ according to Loomis, 1972a).

In this dynamic cooling model, the thickmess of different mineral facies zones is a function of the cooling rate and the ascent rate of the peridotite body. The cooling rate depends on the thermal diffusivity of the peridotite and the temperature difference between the body and the surroundings, which also depends on the ascent rate. If the body rises infinitesimally slowly, the entire body will eventually follow the ambient geotherm and no zonal pattern of mineralogy will be generated. On the other hand, if the body rises rapidly and then stops at some level and cools slowly, it will be recrystallized in low-pressure mineralogies leaving no record of earlier high-pressure and high-temperature mineralogies. If the cooling is fast, however, due to very effective heat conduction, the high-pressure mineralogies survive just as spinel or garnet peridotite nodules are brought up by volcanic eruptions. There are many intermediate cases between these extremes, but the geometry of the $P-T$ trajectories from the primary condition to the recrystallized conditions will generally resemble those illustrated in Fig. 13.

Judging from the textural relations of spinel (e.g. spinel inclusions in garnet; plagioclase mantling spinel grains), the peridotite was probably originally spinel peridotite with or without garnet. Subsequently, garnet and plagioclase formed upon cooling at the expense of the old spinel and aluminous pyroxenes in the garnet-lherzolite and plagioclase-lherzolite facies zones, respectively. Peridotite that cooled along an intermediate path (Sp-Plag Trans, Fig. 13) initially formed more spinel, but later partially transformed to plagiocloase peridotite.

The inferred $P-T$ trajectories have important implications for the igneous and metamorphic history of the peridotite. In Fig. 13 the melting temperatures of a peridotite $(p)$ and a mafic layer $(m)$ are compared with the inferred $P-T$ paths for the peridotite. Note that the solidi are located at higher temperatures than the $P-T$ paths. An implication of this is that the peridotite could not have gone through partial fusion during the ascent and therefore, that the mafic layers must have already been formed before the ascent of the peridotite. If the peridotite is presumed to start rising at higher temperatures, considering the uncertainties in the temperature estimate of the 'primary condition', the $P-T$ trajectories deep inside the body may have crossed the peridotite solidus, resulting in partial fusion of the peridotite. As it cools the body will recrystallize as plagioclase peridotite and the partial melt will recrystallize as gabbro, thus forming the magmatic-type mafic layers. However, field evidence is not consistent with this interpretation; that is, there are, on average, more mafic layers in the higher pressure part of the body 


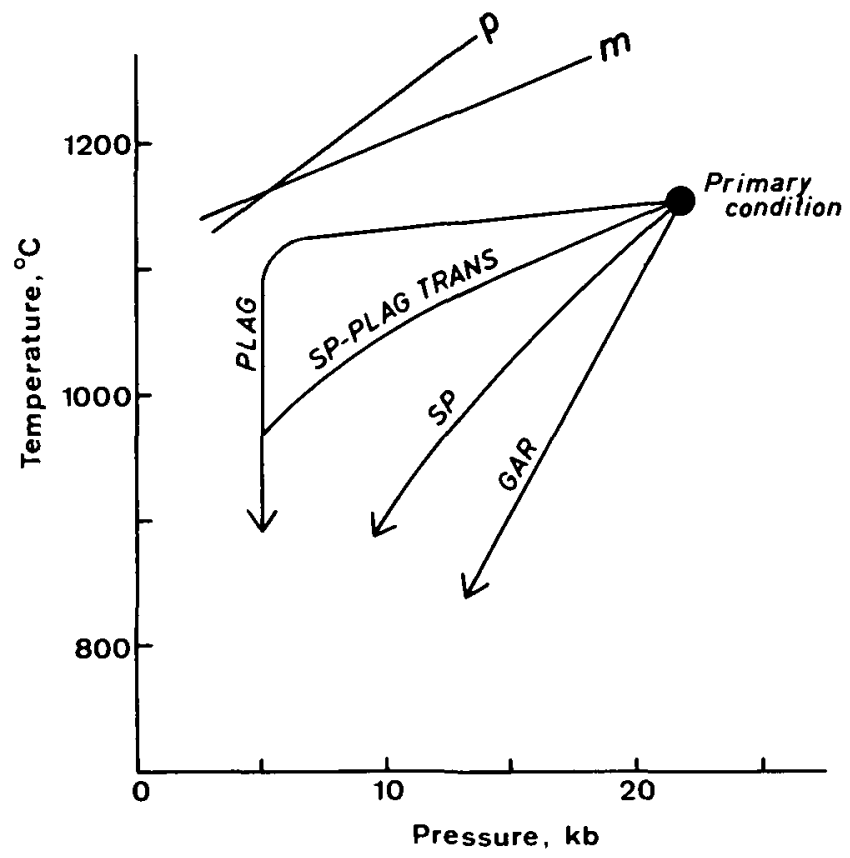

Fig. 13. $P-T$ trajectories for garnet $(G A R)$, spinel $(S P)$, transitional $(S P-P L A G T R A N S)$ and plagioclase $(P L A G)$ peridotites in the Ronda peridotite. $p=$ solidus of pyrolite III (Green \& Ringwood, 1967); $m=$ solidus of a magmatic-type mafic layer from the Ronda mass (R127, Obata \& Dickey, 1976).

(presumed outer part) than in the lower pressure part (inner part) (see Fig. $3 b$ ). Moreover, it is difficult to imagine how the primary enstatite compositions survived such a melting episode. Therefore, I conclude that the partial fusion that was responsible for the mafic layer formation (Dickey, 1970) was prior to the stage of the 'primary condition' and that the peridotite body must already have contained the mafic layers at a depth equivalent to the pressure of the primary condition (i.e. approx. $70 \mathrm{~km}$ depth).

\section{SOME ESTIMATES OF THE PERIDOTITE ASCENT RATE}

An important parameter for the dynamic cooling model discussed above is the ascent rate of the peridotite body. When the peridotite body passes a depth of about $50 \mathrm{~km}$ (corresponding to about $15 \mathrm{~kb}$ pressure, the recrystallization pressure of the garnet peridotite), the outer-most part of the body must be cooled from the initial temperature of about $1200^{\circ} \mathrm{C}$ down to about $800^{\circ} \mathrm{C}$, the recrystallization temperature of the garnet peridotite. The distance $d$ at which the peridotite is half cooled by heat conduction may be approximately related to thermal diffusivity $a$ and time $t$ as follows (cf. Showmon, 1963):

$$
d \cong \sqrt{a t}
$$

Using $0.0089 \mathrm{~cm}^{2} / \mathrm{sec}$ for the thermal diffusivity of the peridotite (cf. Loomis, $1972 b$ ), distance $d$ has been calculated for various times $t$ (Table 9). The ascent rate is obtained simply by dividing $20 \mathrm{~km}(70 \mathrm{~km}-50 \mathrm{~km})$ by the time $t$. 
TABLE 9

Distances of thermal diffusion and chemical diffusion and ascent rate

\begin{tabular}{crrr}
\hline Ascent rate $(\mathrm{cm} /$ year $)$ & \multicolumn{1}{c}{$t$} & \multicolumn{1}{c}{$d$} & $r$ \\
\hline 1 & $2 \mathrm{my}$ & $10 \mathrm{~km}$ & $3 \mathrm{~cm}$ \\
10 & $0.2 \mathrm{my}$ & $3 \mathrm{~km}$ & $1 \mathrm{~cm}$ \\
$10^{2}$ & $20,000 \mathrm{yr}$ & $1 \mathrm{~km}$ & $3 \mathrm{~mm}$ \\
$10^{3}$ & $2,000 \mathrm{yr}$ & $0.3 \mathrm{~km}$ & $1 \mathrm{~mm}$ \\
$10^{4}$ & $200 \mathrm{yr}$ & $0.1 \mathrm{~km}$ & $0.3 \mathrm{~mm}$ \\
\hline
\end{tabular}

$\mathrm{yr}=$ year $; \mathrm{my}=$ million years.

The thickness of the garnet-lherzolite facies zone in the Ronda mass is about 1 $\mathrm{km}$ or less (see Fig. 3c). By comparing this value with calculated values in Table 9, it may be concluded that the ascent rate was probably greater than $1 \mathrm{~m} /$ year. Such a rapid ascent is apparently too fast for any viscosity-controlled movement in the upper mantle, considering that the speed of plate movement is typically 1 to 10 $\mathrm{cm} /$ year (e.g. Le Pichon, 1968). These results imply that the emplacement of the peridotite into the crust was not diapiric (i.e. driven by gravitational buoyancy) as thought by others (e.g. Loomis, 1975) but that it was probably an externally- and tectonically-induced movement in a non-hydrostatic field such as thrusting.

The pyroxene zoning data also constrain the cooling, and thus, ascent rate. Consider a pyroxene grain whose $\mathrm{Al}$ content is being re-adjusted instantaneously to new physical conditions by solid diffusion. As for the case of thermal diffusion, the distance $r$ at which the Al content is reduced by solid diffusion to one-half the initial concentration (i.e. primary composition) may be approximately related to the diffusion coefficient $D$ and time $t$ :

$$
r \cong \sqrt{D t}
$$

The diffusion coefficient is a function of temperature:

$$
D=D_{0} \exp [-E / R T]
$$

where $D_{0}$ is the diffusion coefficient at the standard state; $E$, the activation energy of the diffusion; and $R$, the gas constant. In a cooling environment such as in an ascending peridotite body, the average value of the diffusion coefficient during the cooling period may be used:

$$
\bar{D}=\frac{1}{t} \int_{0}^{t} D d t
$$

Although there are no data on the diffusion of $\mathrm{Al}$ in enstatite, Seitz (1973) gives the diffusion coefficient for $\mathrm{Al}$ in diopside at $1250^{\circ} \mathrm{C}$. Assuming that the $\mathrm{Al}$ diffusivity in enstatite is similar to that in diopside, the diffusion coefficient at $1250^{\circ} \mathrm{C}$ of Seitz (1973) may be extrapolated to other temperatures by assuming a temperature dependence similar to other diffusion data for silicates (Hofmann \& Hart, 1978); for example, $\mathrm{Fe}-\mathrm{Mg}$ exchange in olivine (Misener, 1973). For a linear cooling rate from 1200 to $800^{\circ} \mathrm{C}$, the time-averaged diffusion coefficient $\bar{D}$ is estimated to be approx. $2.3 \times 10^{-13} \mathrm{~cm} / \mathrm{sec}$. Substituting this value into equation (6) gives the diffusion distance $r$ (Table 9). 
In the Ronda peridotite, the grain size of the orthopyroxene porphyroclasts that preserve the $\mathrm{Al}$-plateau of the primary composition is typically of the order of 2 $\mathrm{mm}$. The above calculation for the Al diffusion in pyroxene implies that, in order to preserve the primary composition of the pyroxene, the peridotite must ascend faster than $1 \mathrm{~m} /$ year. This value is in agreement with that estimated from the thickness of the garnet-lherzolite facies zone.

\section{SUMMARY AND TECTONIC IMPLICATIONS}

Summarizing the foregoing petrologic conclusions and published geologic discussions, the emplacement of the Ronda peridotite from the mantle to its present position in the Earth's crust was probably not a single, continuous event but rather it may be regarded as a three-step process. The considerations of the $P-T$ trajectories suggest a stage of igneous differentiation prior to the stage of the 'primary condition'. The hypothetical mantle diapirism that presumably caused partial fusion as originally postulated by Dickey (1970) is, therefore, assigned to the initial motion of the mantle material. The diapirism apparently ceased at some level in the upper mantle and the peridotite-mafic layer complex cooled to the ambient geotherm and re-equilibrated below the solidus at the 'primary' $P-T$ condition (20 to $25 \mathrm{~kb}, 1100$ to $1200^{\circ} \mathrm{C}$ ). A sufficiently long time interval (of the order of a million years) would be required for the peridotite complex to be thoroughly equilibrated at the 'primary' $P-T$ condition. (It was concluded before that the peridotite body had to be thermally equilibrated in order to explain the apparent constancy of the primary compositions of orthopyroxenes from different parts of the mass.) At this stage the peridotite was probably spinel lherzolite \pm garnet; and the mafic layers contained high-pressure mineralogies, i.e. they were pyroxenites or garnet pyroxenites depending on their bulk chemistries.

At some (unknown) time and for some (unknown) reason, this complex started to ascend once again (from $70 \mathrm{~km}$ depth), recrystallizing on its way up to the Earth's crust. The present mineraology and the metamorphic zonation developed at this stage, and each zone followed different $P-T$ trajectories depending upon its cooling rate during the ascent. When the complex intruded into the earth's crust, it produced a contact aureole in the surrounding Paleozoic sediments (now Casares Unit). As distinct from the step 1 motion, this ascent was probably not diapiric because estimates of thermal and chemical diffusion rates suggest that the ascent was much too fast $(>1 \mathrm{~m} /$ year) for any viscosity-controlled movements, and therefore, some externally-induced, tectonic force must be sought for the cause of this movement.

The last motion is a tectonic re-emplacement of the peridotite 'slab' as discussed by Lundeen (1978). Part of the peridotite intrusion was, together with the overlying crustal metasediments (Casares Unit), thrusted over the Blanca Unit (forming the Alpjarride nappe complex).

After recognising these three steps, an important question is then whether these movements are due to a single geotectonic event at a certain period of the evolution of the mantle-crust system (i.e. one orogenic cycle) or to several geotectonically distinct events widely separated in time. Lundeen (1978) argued that the vertical 
(Step 2) and the lateral phases of peridotite emplacement (Step 3) cannot have been widely separated in time if the contact metamorphism of the Blanca Unit (as a result of the lateral re-emplacement) is due to the residual heat in the peridotite slab, and so she regarded them as more-or-less one tectonically continuous process in the Alpine cycle. Timing of the initial diapiric movement is completely open to question, however. In order to proceed with our tectonic history of the peridotite emplacement, we need more accurate radiometric age determinations of the igneous and metamorphic events affecting the peridotite and mafic layers.

It is hoped that the stepwise emplacement scheme proposed here would stimulate further thinking by geologists on the evolution of the Betic Cordilleras orocline, a western realm of the Alpine system (e.g. Torres-Roldan, 1979), and invoke reconsiderations of the emplacement mechanism of alpine-type peridotites in general.

\section{ACKNOWLEDGEMENTS}

This paper has developed from part of my Ph.D. thesis work that was carried out at the Department of Earth and Planetary Sciences, MIT. The manuscript was completed during my postdoctoral tenure at the Institut für Kristallographie und Petrographie, ETH-Zürich. I am deeply indebted to John Dickey for his supervision and encouragement throughout the thesis work. Close collaborations with John Suen and Meg Lundeen were essential to this work. I have benefited much by correspondence with Takeshi Mori and from discussions with the late Prof. C. Goetze on the diffusion calculations and the thermal history. Field assistants were D. Nicole in 1976 and E. Obata in 1974. Technical assistance on the microprobe was given by A. Park, F. A. Frey and V. Trommsdorff read early versions of the manuscript and gave me valuable comments. Jo Laird helped me improve the English as well as providing scientific comments. Constructive criticisms of the referees, H. A. Seck and W. Schubert, are much appreciated. Typing was done by M. Jacobsson. Financial supports were U.S. National Science Foundation Grants GA-41072, DES 73-00264, EAR 76-84067 (to J. S. Dickey) and ETH-Zürich, and they are gratefully acknowledged.

\section{REFERENCES}

AKella, J., 1976. Garnet pyroxene equilibria in the system $\mathrm{CaSiO}_{3}-\mathrm{MgSiO}_{3}-\mathrm{Al}_{2} \mathrm{O}_{3}$ and in a natural mineral mixture. Am. Miner. 61, 589-98.

AlbeE, A. L., \& RAY, L., 1970. Correction for electron probe analysis of silicates, oxides, carbonates, phosphates, and sulphates. Anal. Chem. 42, 1408-14.

Ave'Lallemant, H. G., \& Carter, N. L., 1970. Syntectonic recrystallization of olivine and modes of flow in the upper mantle. Bull. geol. Soc. Am. 81, 2203-20.

Banno, S., 1970. Classification of eclogites in terms of physical conditions of their origin. Phys. Earth planet. Interiors, 3, 405-21.

Boyd, F. R., 1973. A pyroxene geotherm. Geochim. cosmochim. Acta, 37, 2533-46.

Carter, J. L., \& A ve'Lallemant, H. G., 1970. High temperature flow of dunite and peridotite. Bull. geol. Soc. Am. 81, 2181-202.

DanCKwerth, P. A., \& Newton, R. C., 1978. Experimental determination of the spinel peridotite to garnet peridotite reaction in the system $\mathrm{MgO}-\mathrm{Al}_{2} \mathrm{O}_{3}-\mathrm{SiO}_{2}$ in the range $900^{\circ}-1100^{\circ} \mathrm{C}$ and $\mathrm{Al}_{2} \mathrm{O}_{3}$ isopleths of enstatite in the spinel field. Contr. Miner. Petrol. 66, 189-201.

DARot, M., 1973. Méthodes d'analyse structurale et cinématique. Applications à l'étude du massif ultrabasique de la Sierra Bermeja. Thèse du 3e cycle, Université de Nantes. 
Dickey, J. S., 1969. Partial fusion products in alpine-type peridotites: Serrania de la Ronda and other examples. Ph.D. thesis, Princeton University.

- 1970. Partial fusion products in alpine-type peridotites: Serrania de la Ronda and other examples. Spec. Pap. mineralog. Soc. Am. 3, 33-49.

- Obata, M., \& Suen, C. J., 1978. Partial fusion versus fractional crystallization: hypotheses for the differentiation of the Ronda ultramafic massif of southern Spain. Bull. Oregon St. Dept. Geol. Miner. Ind. 96, 79-89.

DüRR, S. H., 1967. Geologie de Serrania de Ronda und ihrer südwestlichen Auslaufer. Geologica romana, 6, $1-73$.

Egeler, C. G., \& Simon, Q. J., 1969. Sur la tectonique de la Zone Bètique (Cordillères Bètiques, Espagne). Verh. Kgl. Akad. Wetensch. Afd. Natuurk, ser. 1, 25.

ENGI, M., 1978. $\mathrm{Mg}-\mathrm{Fe}$ exchange equilibria among $\mathrm{Al}-\mathrm{Cr}$ spinel, olivine, orthopyroxene, and cordierite. Ph.D. thesis, Eidgenössische Technische Hochschule Zürich.

Evans, B. W., \& Frost, B. R., 1975. Chrome-spinel in progressive metamorphism-a preliminary analysis. Geochim. cosmochim. Acta, 39, 959-72.

Ferguson, J., Ellis, D. J., \& England, R. N., 1975. Unique spinel garnet lherzolite from Australia. Geology, $5,278-80$.

Finger, L. W., \& Hadidacos, C. G., 1972. Electron microprobe automation. Yb. Carnegie Instn. Wash. 71, $598-600$.

Fujn, T., 1976. Solubility of $\mathrm{Al}_{2} \mathrm{O}_{3}$ in enstatite coexisting with forsterite and spinel. Ibid. 75, 566-71.

GANGULY, J., 1978. Garnet solid solution and geothermometry based on Fe-Mg distribution coefficient (abstr.). EOS Trans. Am. geophys. Un., 59, 395.

GreEN, D. H., 1964. The petrogenesis of the high-temperature peridotite intrusion in the Lizard area, Cornwall. J. Petrology, 5, 134-88.

_ 1967. High-temperature peridotite intrusion. In: WyLlIE, P. J. (ed.) Ultramafic and Related Rocks. New York: John Wiley \& Sons, 212-22.

— \& Ringwood, A. E., 1967. The stability fields of aluminous pyroxene peridotite and garnet peridotite and their relevance in upper mantle structure. Earth. planet. Sci. Lett. 3, 151-60.

— \& Hibrerson, W., 1970. The instability of plagioclase in peridotite at high pressures. Lithos, 3, 209-21.

HofmanN, A. W., \& HaRT, S. R., 1978. An assessment of local and regional isotopic equilibrium in the mantle. Earth planet. Sci. Lett. 38, 44-62.

IRvine, T. N., 1965. Chromian spinel as a petrogenetic indicator. Part 1. Theory. Can. J. Earth Sci. 2, 648-72.

KornProbst, J., 1966. A propos des péridotites du massif des Beni-Bouchera (Rif septentrional, Maroc). Bull. Soc. fr. Mineral. Cristallogr. 89, 399-404.

Kushiro, I., \& YODER, H. S., JR, 1966. Anorthite-forsterite and anorthite-enstatite reactions and their bearing on the basalt-eclogite transformation. J. Petrology, 7, 337-62.

LAPPIN, M. A., \& SMITH, D. C., 1978. Mantle-equilibrated orthopyroxene eclogite pods from the basal gneisses in the Selje District, western Norway. Ibid, 19, 530-84.

LASNIER, B., 1971. Les péridotites et pyroxénolites à grenat du Bois des Feuilles (Monts du Lyonnais) (France). Contr. Miner. Petrol. 34, 29-42.

Le PIChon, X., 1968. Sea-floor spreading and continental drift. J. geophys. Res. 73, 3661-97.

Lindsley, D. H., \& Dixon, S. A., 1976. Diopside-enstatite equilibria at $850^{\circ} \mathrm{C}$ to $1400^{\circ} \mathrm{C}, 5$ to $35 \mathrm{~kb} . \mathrm{Am} . \mathrm{J}$. Sci. 276, 1295-301.

Loomis, T. P., 1972a. Contact metamorphism of pelitic rock by the Ronda ultramafic intrusion, southern Spain. Bull. geol. Soc. Am. 83, 2449-74.

$1972 b$. Diapiric emplacement of the Ronda high-temperature ultramafic intrusion, southern Spain. Ibid. 83, 2475-96.

1975. Tertiary mantle diapirism, orogeny, and plate tectonics east of the Strait of Gibraltar. Am. J. Sci. $275,1-30$.

LundeEN, M. T., 1976. Structural evolution of the Ronda peridotite and its tectonic position in the Betic Cordilleras, Spain. Ph.D. thesis, Harvard University.

1978. Emplacement of the Ronda peridotite, Sierra Bermeja, Spain. Bull. geol. Soc. Am. 89, 172-80.

— OватA, M., \& Dickey, J. S., 1979. Geologic map of the Ronda ultramafic complex. Geol. Soc. Am. Map and Chart series MC 29.

MACGREGor, I. D., 1970. The effect of $\mathrm{CaO}, \mathrm{Cr}_{2} \mathrm{O}_{3}, \mathrm{Fe}_{2} \mathrm{O}_{3}$, and $\mathrm{Al}_{2} \mathrm{O}_{3}$ on the stability of spinel and garnet peridotites. Phys. Earth planet. Inter. 3, 372-7.

MATSUI, Y., \& NishizAwa, O., 1974. Iron(II)-magnesium exchange equilibrium between olivine and calcium-free pyroxene over a temperature range $800^{\circ} \mathrm{C}$ to $1300^{\circ} \mathrm{C}$. Bull. Soc. fr. Mineral. Crystallogr. 97, 122-30.

MERCiER, J.-C. C., \& Nicolas, A., 1975. Textures and fabrics of upper-mantle peridotites as illustrated by xenoliths from basalts. J. Petrology, 16, 454-87.

Milliard, Y., 1959. Les massifs métamorphiques et ultrabasiques de la zone paleozoique interne du Rif. Notes Serv. geol. Maroc, 147, 125-60.

Misener, D. J., 1974. Cation diffusion in olivine to $1400^{\circ} \mathrm{C}$ and $35 \mathrm{kbar}$. In: HofmaNn, A. W. et al. (eds.) Geochemical Transport and Kinetics. Carnegie Instn. Washington Publ. 634, 117-29. 
MORI, T., 1977. Geothermometry of spinel lherzolites. Contr. Miner. Petrol. 59, 261-79.

$\&$ GreEn, D. H., 1975. Pyroxenes in the system $\mathrm{Mg}_{2} \mathrm{Si}_{2} \mathrm{O}_{6}-\mathrm{CaMgSi}_{2} \mathrm{O}_{6}$ at high pressure. Earth planet. Sci. Lett., 26, 277 -86. 83-97.

Nehru, C. E., \& Wylle, P. J., 1974. Electron microprobe measurement of pyroxenes coexisting with $\mathrm{H}_{2} \mathrm{O}$-undersaturated liquid in the join $\mathrm{CaMgSi}_{2} \mathrm{O}_{6}-\mathrm{Mg}_{2} \mathrm{Si}_{2} \mathrm{O}_{6}-\mathrm{H}_{2} \mathrm{O}$ at 30 kilobars, with applications to geothermometry. Contr. Miner. Petrol. 48, 221-8.

Nicolas, A., Boches, J. L., Boudier, F., \& Mercier, J.-C. C., 1971. Textures, structures and fabrics due to solid state flow in some European therzolites. Tectonophysics, 12, 55-86.

ОватA, M., 1976. The solubility of $\mathrm{Al}_{2} \mathrm{O}_{3}$ in orthopyroxenes in spinel and plagioclase peridotites and spinel pyroxenite. Am. Miner. 61, 804-16.

__ 1977. Petrology and petrogenesis of the Ronda high-temperature peridotite intrusion, southern Spain. Ph.D. thesis, Massachusetts Institute of Technology.

— \& Dickey, J. S., JR., 1976. Phase relations of mafic layers in the Ronda peridotite. Yb. Carnegie Instn. Wash. 75, 562-6.

O'HARA, M. J., 1967. Mineral paragenesis in ultrabasic rocks. In: WYLLIE, P. J. (ed.) Ultramafic and Related Rocks. New York: John Wiley \& Sons, 393-401.

— Richardson, S. W., \& Wilson, G., 1971. Garnet peridotite stability and occurrence in crust and mantle. Contr. Miner. Petrol. 32, 48-68.

OKA, Y., \& MAStumoto, T., 1974. Study on the compositional dependence of the apparent partition coefficient of iron and magnesium between coexisting garnet and clinopyroxene solid solution. Ibid. 48, 115-21.

Orueta, D., 1917. Estudio geologico y petrografico de la Serania de Ronda. Mem. Inst. geol. Espana.

RÁHEIM, A., \& GREEN, D. H., 1974. Experimental determination of the temperature and pressure dependence of the $\mathrm{Fe}-\mathrm{Mg}$ partition coefficient for coexisting garnet and clinopyroxene. Contr. Mineral Petrol. 48, 179-203.

Rost, F., \& Brenneis, P., 1978. Die Ultramafitite im Bergzug südlich des Ultentals, Provinz Alto Adige (Obertalien). Tschermaks miner. petrogr. Mitt. 25, 257-86.

SCHUbert, W., 1977. Reaktionen im alpinotypen Perodititmassiv von Ronda (Spanien) - und seinen partiellen Schmelzprodukten. Contr. Miner. Petrol. 62, 205-20.

SErTz, M. G., 1973. Uranium and thorium diffusion in diopside and fluorapatite. Yb. Carnegie Instn. Wash. 72, 586-8.

SHEwMON, P. G., 1963. Diffusion in Solids. New York: McGraw-Hill.

StRECKEISEN, A., 1976. To each plutonic rock its proper name. Earth Sci. Rev. 12, 1-33.

STROH, J. M., 1976. Solubility of alumina on orthopyroxene plus spinel as a geobarometer in complex systems: applications to spinel-bearing alpine-type peridotites. Contr. Mineral. Petrol. 54, 173-88.

SUEN, J. C., 1978. Geochemistry of peridotites and associated mafic rocks, Ronda Ultramafic Complex, Spain. Ph.D. thesis, Massachusetts Institute of Technology.

Torres-Roldín, R. L., 1979. The tectonic subdivision of the Betic Zone (Betic Cordilleras, southern Spain): its significance and other one possible geotectonic scenario for the western Alpine belt. Am. J. Sci. 279, 19-51.

Wells, P. R. A., 1977. Pyroxene thermometry in simple and complex systems. Contr. Miner. Petrol. 62 , 129-39.

WooD, B. J., 1974. The solubility of alumina in orthopyroxene coexisting with garnet. Ibid. 46, 1-15.

- 1975. The application of thermodynamics to some subsolidus equilibria involving solid solutions. Fortschr. Miner. 52, 21-45.

— \& BANNo, S., 1973. Garnet-orthopyroxene and orthopyroxene-clinopyroxene relationships in simple and complex systems. Contr. Miner. Petrol. 42, 109-24. 